\title{
The Depiction of Apis in the Greco- Roman Tombs of Egypt
}

\author{
Wahid Omran \\ Nagoua Zouair \\ Lecturer in Tourist Guidance Dep. \\ Associate Professor in Guidance Dep. \\ Faculty of Tourism- Fayoum University
}

\begin{abstract}
The bulls' cult was well known during the Greco-Roman in Egypt, especially the bull Apis. Memphis was his main cult center, where his cult was associated with the chief god Ptah, and a priest responsible for both cults. Furthermore, Memphis also contains subterranean galleries for the dead mummified bulls as Osir- Apis. The Ptolemies paid a great attention to the cult of Apis and shared the coronation of the New Apis, and the funeral of the dead one. They integrated the cult of Serapis, the chief god of the Ptolemaic Kingdom, as the Hellenization form of the Egyptian Osirified Apis bull. Moreover, The Romans paid respect to the cult of Apis inside Egypt, and outside either. Apis's prominence during the Greco-Roman period added him new aspects in both funeral and burial customs. The research tries to identify the new attributes of Apis in the Greco-Roman tombs as a funerary god, besides, other roles initiated from his integration with other gods. Apis was a main figure not only in the decorated Greco-Roman tombs of Egypt, but also upon the stelae, the Mummy Coffins and Mummy Cartonage of Egypt. He appeared as a burial god; equated with Osiris and Dionysos. His association with Serapis in the Hellenistic Egypt represented him as the protector of the kingship of Egypt. Ptolemaic and Roman rulers depicted themselves under his respect, and either spread to the Hellenistic world with Isis as her husband. In addition, his cult appeared in the Roman Isaeums in Rome, and the other Hellenistic temples consecrated for her with the Egyptian figure as a bull. Apis was the carrier of the deceased in the netherworld, and he appeared in the judgment's court of the deceased. He either performed the role of Isis and Nephtys as the deceased's guardians in his tomb, as they did with Osiris, and as protectors of the fetish of Abydos.
\end{abstract}

Keywords: Apis bull, Cult, Greco-Roman period, Serapis, Memphis,Osir-Apis

\section{Introduction}

Since early times, cow and bull cults were widespread in Egypt. In later times, this became more prevalent. ${ }^{(1)}$ in the first dynasty; the worship of the bull Apis appeared, ${ }^{(2)}$ besides a priest for his cult since the fourth dynasty. The worship of the Apis bull had a close relation with the pharaoh. ${ }^{(3)}$ Memphis was his cult center, its necropolis belongs to the living bull Apis, ${ }^{(4)}$ whose cult was mainly associated with the temple of Ptah at Memphis. ${ }^{(5)}$ The coronation of the bull Apis was held within the temple of Ptah, with the attendance of about hundred of priests - according to Roman historians- from all over Egypt. ${ }^{(6)}$

Between1850-1853, Mariette explored the burial shafts of the Apis bulls, ${ }^{(7)}$ these were dated back to the reign of Ramses II. Many underground galleries of the mummified Apis bulls date back to the Late Period, with the predominance of the worship of the sacred bulls in Egypt, especially during the reign of Pasmatik I, ${ }^{(8)}$ and Amasis. ${ }^{(9)}$ The earliest recorded burial of a sacred animal was the Isis cow -the mother of Apis- in the Necropolis of Hepnebes. ${ }^{(10)}$ according to Herodotus, Amasis was the founder of the great temple of Isis in Memphis. ${ }^{(11)}$

The association of Apis with Osiris as 'Osiris- Apis' or 'Apis-Osiris' began from the $18^{\text {th }}$ dynasty; as the mummified Apis in the Serapieion of the desert of Memphis. ${ }^{(12)}$ In the Ptolemaic period; Osiris was identified with god Serapis, who was considered the stiff Hellenized form of Osiris. ${ }^{(13)}$ The association of Serapis and Osiris dated to the $3^{\text {rd }}$ century B.C through the reign of Ptolemy I (Soter), as an incarnation of Osiris-Apis (Osor-Hapi), the deified bull of Memphis. ${ }^{(14)}$ Rendering to the command of the god Hades in the king Soter's dream, he exported the statue of the god from Sinope. ${ }^{(15)}$ Later, primary Ptolemies regarded Serapis as the ideal source to create a dynastic god without genuine Greek roots. ${ }^{(16)}$ In one oblique reference from athenodorus of tarsus, which states Osirapis was originated from the association between Osiris and Apis. ${ }^{(17)}$ This emphasizes Serapis was often nothing, other than an interpretation of Graeca of Osiris. $^{(18)}$

Alexander the Great conquered Memphis and made offerings and scarifications before the bull Apis. ${ }^{(19)}$ When Ptolemy I ruled Egypt; the cult of Osir-Apis became the chief cult; not only in whole Egypt, ${ }^{(20)}$ but in the Hellenistic world either. ${ }^{(21)}$ The name was pronounced by the Greeks as 'Osorapis', patronized by the early Ptolemies as Serapis. The Egyptians depicted Serapis as a bull worshiped in the Serapeum of Memphis, while, the Greeks depicted it in human form, in the new 'Serapeum' temple in Alexandria. ${ }^{(22)}$ Therefore, his worship spreaded all over Egypt. ${ }^{(23)}$ The Ptolemaic efforts and propaganda succeeded to put the Egyptian "Osarapis", the Hellenistic "Serapis" as the chief deity of Alexandria, P. Oxy described "Osarapis" as "master of Alexandria". (24)

In Abydos, both Osiris and Serapis refer to one god. ${ }^{(25)}$ The graffiti dedications of the visitors of Seti I's temple, the stelae, and the grave reliefs of the Ptolemaic period in Abydos necropolis, these confirm this assimilation. ${ }^{(26)}$ The Classic writers mentioned this connection. ${ }^{(27)}$ Sarapis was a fusion of Osiris with the bull Apis of Memphis, and the term "Osorapis" clearly refers to the souls of the dead Apis bulls, whose souls have become part of Osiris as the 
Osirified bull. When Apis died, the country mourned, the death of Apis led to frantic searching up and down the country until his successor could be found, ${ }^{(28)}$ perhaps the priest of Ptah was responsible for. ${ }^{(29)}$ When an Apis bull had found it brought to Memphis, and crowned in the temple of Ptah, Ptolemy might officiate, however, the high priest of Ptah performed the ceremony. ${ }^{(30)}$

Seventy-day long preparations for burial commenced at once. ${ }^{(31)}$ The ritual, with detailed instructions on how to mummify, survived in a part of a bilingual papyrus text, in both hieratic and demotic. Dramatic ceremony was held through the seventy days. After the coffin of Apis was hauled out of the 'Embalming House' ${ }^{(32)}$ placed within a shrine, and then upon a boat with a wheeled base (pl. $1 \mathrm{a}, \mathrm{b}, \mathrm{c}),{ }^{(33)}$ to enable him passes through the pharaoh's lake, ${ }^{(34)}$ with the participations of Egypt's great gods; such as the divine sisters mourning the god; Isis, Nephtys, ${ }^{(35)}$ two Wepwawetwolf gods-, gods of the north and the south, who opened the ways. Those were followed by Horus, Thot, and then Apis bull in the rear. On his arrival at the shore, Apis was placed again on a sand couch, his face turned towards the south. Priests with scepters and staffs in their hands embarked in a papyrus boat, the sacred bark of Re and Osiris, to make passing over and reading the nine holy books during the sailing of Apis, mentioning the battles in mythical times, of Horus and Seth, Re, and the serpent Apophis. ${ }^{(36)}$

A canopy was erected on the shore; Apis enters it from the west, and gets out from the east to mark his resurrection. Opening of mouth ritual was done by Anubis' priests to bestow new life to the bull, which returns to the embalming house through the Gate of Horizon, where the sun roses as a cosmic resurrection, then the priests threw the mshn.t brick down before him to secure resurrection. ${ }^{(37)}$

On the seventieth day; the mummified bull as 'Osiris-Apis' was to join the other Osiris cults of the Memphite necropolis in the desert, ${ }^{(38)}$ where the burial shaft was well prepared in advance. However, the huge granite sarcophagus had to be dragged into place and prepared for the final closing of the shaft. ${ }^{(39)}$ The 'Pavilion of Appearance'; the place where the bull was kept, lived, and died, has a window opens to the temple of Ptah, and from its southern entrance, ${ }^{(40)}$ the crowds gathered by thousands as molytes, mourners, and watchmen. ${ }^{(41)}$ A special police officer was charged for controlling and discipline. The first documented burial of Apis was in the $37^{\text {th }}$ year of Amasis's lifetime between $664-$ 525. However, the last burial was on the $11^{\text {th }}$ year of the queen Cleopatra VII's reign. ${ }^{(42)}$

The Greeks assimilated the deified Apis with their god Dionysos. They interpreted these Memphite rituals in terms of Dionysiac mysteries. The Greeks located Memphis within the traditional Greek topography of Hades. The pharaoh's lake; which Apis crossed, this was of Acherousia. Staffs and scepters of the priests become Dionysiac Thyrsoi. While the dress; which Anubis's men wore was nebrides, the fawn skins. The great gates of the Sarapieion were those of Lethe and of Kokytos, bound in bronze and found within the temple of Hekate. ${ }^{(43)}$

Although the god Apis was worshipped all over Egypt; Memphis was the cult center. His cult associated with kingship, ruling power, ${ }^{(44)}$ and Apis has a special oracle at Memphis either. ${ }^{(45)}$ Moreover, Classical authors stated he was well known for the oracles and fortune-telling associated to the cult either. ${ }^{(46)}$ Many pilgrims and tourists visited him in his stall close to that of Apis's mother. ${ }^{(47)}$

During the Roman period, sacrifices were made for the bull, ${ }^{(48)}$ Greek settlers had ample chance to interpret their dreams and future foretold inside the temple of Osir- Apis at Saqqara, ${ }^{(49)}$ which still attracting sightseeing, the bull's reputation of foreseeing the future. For others, the prophecy came through children whether playing or speaking aloud. Apis oracle had a constant tradition. ${ }^{(50)}$

The oracular role of Apis associated with Thot, enjoy a popular vogue. They were further connected with the interpretation of dreams, ${ }^{(51)}$ both were connected with Astronomy and Astrology. Moreover, the bull was associated with magical qualities, ${ }^{(52)}$ pilgrims increasing with the site's fame to ask the god to make their demands true. ${ }^{(53)}$ The necropolis was once enclose several guest households and catering shops. In addition; the papyri inform us, a large number of highly specialized occupation, butchers, beakers, inn-keepers, launderers, porters, and water-carriers were existent there. ${ }^{(54)}$

\section{Scenes of Apis in the Graeco- Roman tombs \\ 1. Kom el- Schukafa \\ Scene no.1, on the rear wall of the burial chamber's right side niche}

The bull Apis standing upon a battered pedestal with a denticulate upper molding, decorated with teeth-ornaments. It is standing opposite to the central niche. Before the stand is a small altar, the bull marked with a crescent on his side, wears a solar disc between his horns, and a Naos-shaped emblem on a cord around his neck. A string of amulets hangs above him with festoons and wd3t-eye. A Roman emperor paying homage to the Apis bull in the custom of a pharaoh, ${ }^{(55)}$ appeared in an incised kilt similar to the one Horus wore, but decorated with a feather pattern like the kilt of Thot, a short mantle across his neck, and a pschent crown. He is offering a decorated collar to the bull, the Menat-collar. Behind Apis; stands Isis-Maat with outstretched wings for protection, holding the ostrich feather of Maat in her left hand. She wears a band with a Uraeus across her brow, and she is crowned with a disc fronted by a second Uraeus $(\mathrm{pl} .2){ }^{(56)}$ 


\section{Scene no.2, on the rear wall of the burial chamber's left niche}

This scene is identical to the previous one; Apis is depicted standing upon the similar pylon-shaped plinth, and the Roman emperor as a pharaoh is offering the same decorated collar. The only change is the bull has a distinct crescent, a cord with festoons and the wd3t-eye within a circle marked on its flank. Moreover, an altar is in between the Pharaoh and Apis, while goddess Isis-Maat protects him by her outstretched wings (pl.3). ${ }^{(57)}$

\section{Tigrain's Tomb}

\section{The upper panel on both sides of the burial chamber's entrance corridor}

Two signal figures of the bull Apis on the sidewalls of the burial chamber's entrance corridor. Standing figure of Apis is painted in brownish red and white, a dark-brown crescent is on his side, and his belly is painted white. ${ }^{(58)}$ Both of them directed towards the burial chamber, with their right legs forward. A male figure below each of Apis figures is in the lower panel. It is standing to the left, with a situla in his right hand, and an 'Ankh-sign in his left hand. An adjacent panel shows a long serpent with lotus-headdress (pl. $4 \mathrm{a}, \mathrm{b}, \mathrm{c}){ }^{(59)}$

\section{Gabbari Tomb}

Scene no.1, Tomb A - Habachi's tomb ${ }^{(60)}$

On the right side of the niche of the burial chamber

Two recumbent figures of Apis on an Egyptian posture with battered sides are facing the tomb's visitors. Their foreparts are painted yellow, while, their bodies are painted green in one time, and red in the other (pl.5). ${ }^{(61)}$

\section{Scene no.2, The Sieglin tomb-Gabari $5^{(62)}$}

On both hands of lateral facade walls.

A striding bull Apis, a crouching griffin, and a recumbent Apis are depicted stacked vertically upon a delicate floral stand, creates the impression of a candelabra on the right side. Three matching figures are also depicted on the left side (P1.6). ${ }^{(63)}$

\section{Minet el-Basl (Wardian) ${ }^{(64)}$ \\ On the right side of the niche of tomb $A$.}

Apis is standing upon a pedestal, and Isis is protecting him by her outstretched wings (pl.7). ${ }^{(65)}$

\section{Mafrusa}

Upon architrave of a loculus in the hypogeum of Mafrusa $3^{(66)}$

Destroyed plaster-decoration portrays two opposite figures of Apis upon pedestals. Each bull's horns are flanking a solar disc, and a collar surrounds their necks. ${ }^{(67)}$ Before the two figures; is an altar, while behind, is a damaged inscription. ${ }^{(68)}$

\section{Dakhla Oasis}

\section{Scene no.1}

The western wall of the antechamber of El-Mazawka, tomb of Petosiris

The scene depicts seven gods in different figures. They are shown holding natron bowls in their right hands, and mummy bandages in their left. They are followed with sons of Horus in their traditional figures, then a goddess with wd3t-eyes; so entitled as wd3t-goddess. This goddess holds an incense flame in her left hand, and a scepter in her right. She is standing before the deceased's (Petosiris) cenotaph, who is lying as a mummy inside, and the falcon Horus stands upon his body. The bull Apis stands upon the cenotaph with the solar disc between its horns, which in turn topped with two ostrich-feathers. A collar with b3t symbol surrounds the bull's neck (pl.8). ${ }^{(69)}$

\section{Scene no.2}

El-Mazawka, tomb of Petubastis, the lower register of the burial chamber's northern wall

Petubastis adores two Apis bulls, which are venerating the sun's fetish (pl.9). ${ }^{(70)}$

\section{Akhmim}

Tomb IV, the rear wall of the burial chamber's niche ${ }^{(71)}$

The niche contains three scenes; the third one depicts the deceased in a white Roman robe is making offering before a standing figure of Apis in reddish colour, remains of a pedestal, and an altar in between. (pl.10)

Tomb C3, Scene 1. The left side of the north wall

The wall also contains a damaged scene, hardly depicts a damaged figure of the deceased in a white Roman robe, probably in adoring attitude. He is standing before a partially damaged crouching figure of the bull Apis on a shrine decorated with long striped lines in brown and black colors. Between the bull's legs; is the representation of the djedpillar, besides two festoon decorations; one above and the other is behind the deceased (pl.11). 


\section{Scene 2. The eastern wall of the burial chamber}

The fifth scene upon the wall shows gods Thot and Horus while erecting the fetish of Abydos, topped with two feathers and a red sun disc in between. Two bull figures are flanking the fetish; each figure is standing upon a standard, the scene is bordered by two festoons, and topped with another (pl.12).

\section{Tomb C5, The southern wall of the burial chamber}

The upper one shows a damaged female figure in a white Roman garment. She is rising her hands in adoring-attitude before a damaged figure of the bull Apis, who is surmounting the deceased's cenotaph, where his mummy is lying, and decorated in red and black, then the fire lake with an eidolon "Skeleton" inside. ${ }^{(72)}$ Then a partially damaged figure of the legendary animal, the Devourer "Am Am". The wall's lower register contains a judgment's scene (pl. 13a, b).

\section{Conclusion}

1- During the Greco- Roman period; the bull Apis has diverse aspects with different functions. The association between Apis and Serapis at Memphis attributes them to Serapis' function as a god of oracles, healing, and interpreting dreams. ${ }^{(73)}$ depending on the existence of a shrine of Serapis inside the precinct of the bull Apis. ${ }^{(74)}$ Moreover, he was associated with the sun's cult of Re. he was called as the son of Re, similar to the Serapis' identification with the sun. While the Apis' relation with Osiris gives him the function as god of the dead, symbol of fertility. His connection with the inundation, linked him with women's sexuality, ${ }^{(75)}$ and was considered a lunar-god either. ${ }^{(76)}$

The association of Serapis (Apis) and Dionysios at Memphis and Alexandria, enter him to the mythological Dionysos-Hades- Osiris cult, ${ }^{(77)}$ so Osiris was considered as the father of Apis. ${ }^{(78)} \mathrm{He}$ was associated with particular intimacy with the pharaoh. Furthermore, in the Graeco- Roman period, he was connected with the cult of Isis, as the representation of the young cow Isis- Hathor. ${ }^{(79)}$

2- The representation of the bull Apis upon the walls of the Graeco- Roman tombs related to his incarnation of Ptah, and Osir-Hapi, was worshipped at Saqqara. The Greeks identified him as "Epaphus" in red color. The depiction of the bull Apis upon the tombs' walls was due to his association with the Osiris myth. Horus took the form of the bull Apis, while, Isis represented in a cow (hrsh3) figure when chasing the killer Seth. They succeeded to hold him, subsequently they brought Osiris in the city of Apis (hp.t). ${ }^{(80)}$ According to this legend, the bull Apis's cult was associated with other major cults in the Graeco- Roman tombs of Egypt:

- The father Osiris (the defied bull Apis), who was entered the cycle of the Osiride cult after his death. ${ }^{(81)}$ Moreover, he was assimilated with Osiris in the Serapeum of Memphis, ${ }^{(82)}$ in the tombs, and on the stelae (pl. 14). ${ }^{(83)}$

- The mother Isis (the mother-cow) as the mother of Apis galleries of North-Saqqara, contain many sarcophagi and mummies for the mother-cow of the bull Apis. ${ }^{(84)}$ The cow Isis associated during the Graeco- Roman period with Hathor as Isis-Hathor or Hathor-Isis as the bull Apis's mother. ${ }^{(85)}$

- The son Horus (the young calf). ${ }^{(86)}$

- The consort of Hathor. The association between Apis and Isis as his mother, furthermore, it creates a normal link with Hahthor; described as "the greatest cow, who Re has born". Moreover, Apis accompanied Hathor at her shrine at Deir el- Bahari as her counterpart, and her consort either. He was described in the temple of Deir el-Bahari as "Apis, the bull, who inseminated the cows", Hathor who was the kings' nursing mother (the incarnation of Horus and Sons of Re). ${ }^{(87)}$ as a result, the famous healer saint Amenhotep son of Hapu at Deir el-Bahari was attributed to Apis - not Hapu- as his father and to Hathor - not Itit- as the mother. $^{(88)}$

3- The bull Apis was a common deity of Alexandria and a familiar figure in tombs there. Rendering this; the main tomb of kom elSchukafa, most probably dated back to the $1^{\text {st }}$ century A.D; encloses a scene of a Roman emperor venerating the bull Apis in the presence of Isis is unique for two reasons:

First: the suffering of the Egyptian deities; like goddess Isis at Rome; on the second half and either the first half of the $1^{\text {st }}$ century B.C. Her cult was prohibited, besides; the Senate and early Roman emperors had destructed her altars and sanctuaries. Augustus and Tiberius banned it, but Caligula reinstated it. He - Caligula- rebuilt the Iseum on the Campus, which Tiberius destructed. Only the end of the Julio- Claudian reign, the Isiac's worship was part of the Roman state religion. ${ }^{(89)}$

Second: the animal- figure of Apis, though during this period, worshipping animals was still strange and not acceptable to the Romans. ${ }^{(90)}$ Therefore, early Roman emperors most probably associated with Isis, through her Hellenistic consort figure Serapis and his adjunct the bull Apis.

Venit suggested most probably Vespasian is the Roman emperor depicted under the homage of the bull Apis. On July $1^{\text {st }}$ 69 A.D, Nero sent Vespesian and his son Titus to Jerusalem to suppress the Jewish rebellion there. A year after, the Roman troops in Egypt proclaimed emperor Nero's suicide. ${ }^{(91)}$

Vespasian left Titus in Judea to continue his war, and travelled to Alexandria. ${ }^{(92)}$ He visited the Serapeum, to ask the god about the permanence of his position. ${ }^{(93)}$ He performed miracles at Alexandria under the auspices of Serapis, curing one man of a crippled hand and causing another blind to see. ${ }^{(94)}$ He visited Alexandria in the Winter of 69-70 A.D, and departed in August of 70 A.D. ${ }^{(95)}$ Later Titus visited Alexandria, on his way to Memphis in 70 A.D, he consecrated the bull Apis. ${ }^{(96)}$ When Titus 
attended the installation of the bull Apis, wearing a diadem, according to the custom and rite of the ancient religion. ${ }^{(97)}$ The event's significance did not go unremarked in Rome.

Venit suggested the tomb dates back to the Flavian's period, and Vespasian was the emperor depicted four times on the walls of Kom- el-Schukafa tomb for three reasons, these are;

First: his proclamation as a Roman emperor was by the Roman troops of Egypt- not at Rome- on the $1^{\text {st }}$ of July 69 A.D. ${ }^{(98)}$ Second: he was honored in Alexandria as the son of Re, God Cesar, and the son of Ammon.

Third: Dio Cassius's referred that Vespasian entered Alexandria while the Nile was over flowed, this had taken place only once before, perhaps he came from Memphis, ${ }^{(99)}$ specially Memphis has a very important trading harbor, mainly with the Arsinoite Nome of Fayoum. ${ }^{(100)}$ The payment of the Memphite harbor tax; eventually made to its own Grammateus, this suggests a destination along the Nile, often, beyond Alexandria, besides other cities of the Delta. Furthermore, Memphis was a center of shipping and shipbuilding. ${ }^{(101)}$

Identifying and recognizing the real character of the Roman emperor at Kom el-Schukafa was such a big debate among the scholars. Thompson suggested this was recorded for posterity in the burial chamber of Kom el-Schukafa. Kater-Sibbes and Vermaseren hestated in suggesting the king of Kom el-Schukafa may be the Roman emperor Titus. ${ }^{(102)}$ Malaise, ${ }^{(103)}$ Pfeiffer ${ }^{(104)}$ and Thompson, ${ }^{(105)}$ suggested the depiction of a king before Apis at Kom el-Schukafa might allude to this incident of Titus's. Specifically Suetonius, ${ }^{(106)}$ stated Titus was not emperor at that time (thus the rumors), while the scene depicts a king wearing the double crown. Kaplan assumed a new hypothesis, the deceased is in the form of a king sacrificing before Apis. In the Roman period, the deceased always seek to become Osiris NN, and here the deceased is depicted as Osiris in his function as a king. ${ }^{(107)}$

The identification of the Roman emperor in his Egyptian figure at Kom el-Schukafa, discovers not only the one who is venerating Apis, but gives the specific date of the hypogeum. Some Scholars try to specify the date according to the architectural style of the Triclinium style of the main tomb of Kom el-Schukafa. The Triclinum- shaped hypogeum appeared on the coins between the reign of Trajan's reign and the time of a son of the emperor Licinius, almost after 324 A.D. ${ }^{\text {(108) }}$ Von Bissing assumed this shape dates back to the period between the reign of Vespesian and Hadrian. ${ }^{(109)}$

Kaplan agrees the assumption; the hypogeum dated to the period from the end of the $1^{\text {st }}$ century till the beginning of the $2^{\text {nd }}$ century A.D. Furthermore, this still in use till the $4^{\text {th }}$ century A.D. ${ }^{(110)}$ Bernand stated; the hypogeum dates back to the reign of Antonius Pius or Septemius Severus. ${ }^{(11)}$ Other scholars attempt to date the hypogeum according to the artistic view of the hairstyle of two statues before the main tomb of Kom el-Schukafa, or according to the statues found in the Rotunda's well. Botti suggested; the male figure dates back to Antonius Pius's reign. ${ }^{(112)}$

Empereur attributed the female statue's hair-style to the end of the $1^{\text {st }}$ century A.D. ${ }^{(113)}$ While Th. Schreiber, ${ }^{(114)}$ suggested the two figures dated back to the end of the $1^{\text {st }}$ century A.D. Lembke mentioned the man's hair-style was similar to the emperor Titus's style. While the woman's hair-style was attributed to the empress Agrippina (15-59 A.D wife of Claudius. ${ }^{(115)}$ One of the marble busts of the Rotunda (Greco-Roman Museum, Nr. 40.3469) attributed to Hadrian, another one (Nr. 3.3516) attributed to Titus or Domitian. ${ }^{(116)}$ El-Fakharani dated the tomb to Antonine's period. ${ }^{(117)}$ A. Rowe assumed the tomb dates between the $1^{\text {st }}$ and the $2^{\text {nd }}$ century A. D, and still in use till the $4^{\text {th }}$ century A.D. ${ }^{(118)}$ Adriani, ${ }^{(119)}$ and Fraser, ${ }^{(120)}$ assumed the $1^{\text {st }}$ century A.D the right dating of the tomb.

No doubt Vespasian has an Egyptian ritual's inspiration, he paid great homage to god Serapis in Alexandria, and prayed before him in the Serapeum of Alexandria, where Serapis was the protector of the imperial cult of Vespasian. Moreover, he attributed his victory on the Jewish rebellion to Serapis. He get into the Serapeum's sanctuary alone; asking Serapis the permanency of his position, and held the title "Son of Amon". Vespasian wanted to keep on Alexander the Great's steps, ${ }^{(121)}$ who visited Siwa, get alone into Amon's sanctuary requesting power, stability, and future. Furthermore, he was named as the Son of Amon. A $1^{\text {st }}$ century B.C papyrus contains an invocation where Alexander asking Serapis to take up residence in the new Alexandria and his temple for Serapis in the city. ${ }^{(122)}$ Therefore, it was logic, Vespasian hoped to follow Alexander's religious ambitions; to visit Memphis and assist his coronation in the native Egyptian town, and paying homage to Apis; the other face of Serapis, as Alexander had acted before.

Vespasian and his son Titus, spent the night within the Serapeum and the Iseum in Isis's temple of the Champ of Mars, in Rome ${ }^{(123)}$ sharing the victory's celebration of Jerusalem in the precinct. This is a new way to affirm the link between Egyptian gods and power, in its most spectacular show. ${ }^{(124)}$ Therefore, Vespasian is most probably the Roman emperor who venerated Apis at Kom el-Schukafa.

The appearance of goddess Isis behind Apis, suggested her normal role as the guardian of the dead Apis (as Osir-Apis) as his wife. The worship of Apis in Alexandria was mainly connected with the Isiac cult, specially his cult was accompanied with Isiac sanctuaries outside Egypt. ${ }^{(125)}$ Therefore, Isis spread her wings to bestowing protection to the Osiris-Apis.

Offering the broad Menat collar for the deified bull Apis on the walls of Kom- el schukafa emphasizes the association between the cults of Apis and Isis in the Greco- Roman period. The Menat-collar was an important attribute for the cow-goddess Hathor from the Middle Kingdom, or for Hathor-Isis since the New Kingdom. ${ }^{(126)}$ However, during the Greco- Roman period, as a result of the close relation between Hathor- Isis and Apis, the collar was attributed to the bull Apis, where many bronze 
statues of Apis were found wearing the Menat. ${ }^{(127)}$ Kaplan suggested, according to the association with Apis, the domination, and royalty; offering the collar to Apis will bestowing the deceased a guarantee of the rejuvenation and the protection of the person and his tomb. ${ }^{(128)}$

Offering the Menat to Apis can be affirmed also outside Egypt. This has occurred in Italy, on one side of an obsidian cup with Egyptian ritual scene, from Stabiai. It depicts a man -wearing a short mantle- while offering a collar and a lotus-flower to Apis (pl. 15). ${ }^{(129)}$ The same broad-beads collar is depicted also on one of the columns of the Iseum Campense, ${ }^{(130)}$ where a man is offering the collar to the priest of Isis. This indicates the offering of this collars' type connected to the cult of Isis (pl. 16). ${ }^{(131)}$ The offering of the broad collar is an important element of burial equipment. In chapter 148 of the book of the dead; the deceased hope to has a golden collar, which ensuring the deceased an eternal power. ${ }^{(132)}$ Offering a collar to Apis is also seen upon one of the tombs of Petosiris at Tuna el-Gebel (pl.17). ${ }^{(133)}$

4- Each short entrance wall in the tomb of Tigrainis was divided vertically into two zones in two registers, the upper one depicts the bull Apis, while the lower depicts a male acolyte of Isis guides the visitors into the tomb. The two male figures depicted on the lower register appeared as Isis adherents and wearing the same garment of Isis's pastophori (shrine bearers or priests of Isis). Their garments tied under their pectorals, and holding the situla. ${ }^{(134)}$ The Isiac mummied-form cultic vessel, characterized by high looped handle, flaring mouth, and round or piriform shape with a knob at the bottom. ${ }^{(135)}$ In addition, it is striated horizontally to import a sense of sphericity and a silvery sheen. ${ }^{(36)}$

The two male figures and the Apis bulls are the first images to greet and accompany the tomb's visitors. Their placement at the entrance to the burial chamber is the key to illuminate their narrative scenes. ${ }^{(137)}$ They are painted in a formalistic Egyptian manner, and garbed in traditional Egyptian short kilts, though bound around their pectorals, and wear the pharaoh's nemes headdress, and beneath their chins, lines indicate they also wear the false beard of a pharaoh. ${ }^{(138)}$ They are depicted in the form of a pharaoh or a priest. Empereur suggested, they are pharaohs. ${ }^{(139)}$ Picard stated, they were connected with the cult of Isis, as an Isiac's figure. ${ }^{(140)}$ While Venit suggested these two Egyptian pharaohs' figures are completely differ from the two-pharaohs of Kom el-Schukafa. They do not represent a pharaoh, rather than an "Egyptian figure" as "pastophori" Isiacs' priests" in one of the Roman tombs of Alexandria. ${ }^{(141)}$ Relating to the influence of Egyptian religious concepts in Roman tombs of Alexandria, this appeared in this pharaoh's figure presents a form of employing them in the Graeco-Roman tombs. ${ }^{(142)}$

The appearance of the bull Apis twice with Isis followers on the entry corridor to the burial chamber. It emphasizes Apis is the personification of the Egyptian Osir- Apis, the Hellenistic figure; Serapis, Isis's consort in Egypt during the Greco- Roman Egypt. The worship of Osiris in the Hellenistic period was almost merged in the form of his syncretism with Dionysos. ${ }^{(143)}$ Osiris was venerated in the Greco-Roman period in Alexandria, ${ }^{(144)}$ and frequently appeared in iconic form on funerary monuments in Roman Egypt. ${ }^{(145)}$

5- The appearance of a pair of Apis bulls is popularly depicted in tombs of Alexandria, as Habachi's tomb, Sieglin's tomb at Qabbari, and Mafrusa Tomb Nr.3. In Tigrain's tomb, a single figure of bull Apis is depicted on each side of the burial chamber's corridor. On Sieglin's tomb, these are depicted separately in a recumbent attitude. On Habachi's tomb, these figures are depicted as a couple (one in green color, and the other is in red) recumbent on the same pedestal. While on Mafrusa's tomb, these figures are depicted opposite to each other, and an altar is depicted in between. Furthermore, the paired bulls were well-known outside Alexandria tombs; of these, the tomb of Petubastis at Dachla, and upon the shroud of the tomb of Bocchoris at Saqqara. ${ }^{(146)}$

Kaplan suggested the two bulls' figures, as in Habachi's tomb, resembles Apis and his mother. ${ }^{(147)}$ While Venit referred doubtingly the green color might relate to the Osirin association of the bull Apis due to the other red color. ${ }^{(148)}$ probably, the one in red refers to the living Apis, while the green one refers to the dead Apis (Osir-Apis). Another explanation stated; one refers to the bull Apis, while the other attributes to Mnevis bull of Heliopolis, ${ }^{(149)}$ in accordance to the connection between Alexandria and Heliopolis during the Greco- Roman period. ${ }^{(150)}$

Whitehouse supposed the appearance of the paired bovides on the shrouds, or the tombs' walls, according to their representation on the shroud of Bocchoris's tomb at Saqqara (pl.18). These could be wooden images, draped and kneeling as in Herodout's description of the Saite cow, or may be as mummies. ${ }^{(151)}$ Edda Breschiani described the bull Apis standing alone on top of the shroud as the son of Isis. ${ }^{(152)}$ Furthermore, she assumed another one on the corresponding area to the right side of the shroud, which is completely destroyed. Typically, it contained identical figure of a bull, probably the sacred Mnevis-bull of Heliopolis. It stands opposite to Apis figure at Saqqara. Furthermore, Bresciani assumed the other crouching opposite bulls in the scene's core, resembling two mummies. These may belong to Apis and his mother Isis, or Apis and Mnevis of Heliopolis. If the later; they could be seen as funerary doubles to the living bull(s) depicted at the shroud's top, with the nearby figure of Anubis as their embalmer. ${ }^{(153)}$

Whitehouse referred their headgear, however, the disc, feathers, and horns typical of Isis-Hathor, these indicate to cows not bulls; though the curly hair on their bulls, which is not mainly attributed to the bulls. Therefore, they may display two cows' representations, as mothers of Apis and Mnevis, the white h3st-cow of Aphroditopolis, worshipped at Aphroditopolis. ${ }^{(154)}$ Thus their combined appearance as cows in the tombs or shrouds, signify the role of Isis and 
Nephtys, who are depicted wearing green dresses with purple sashes knotted under their breasts, the same colors of the combined cows. ${ }^{(155)}$

He indicated the assumed opposite figures of Apis and Mnevis at the top of the shroud, associate with the sun and the moon cult. The image of the sun as infant god sitting in his boat, and the moon as a female figure on a crescent, while Isis and Nephtys are raising their hands in adoring attitude for the sun and the moon. While two goddesses of the east and the west, and the bulls are incarnations of the sun and the moon, who were born in the east, and encounter each other on the day of meeting the two bulls as the time of full moon. ${ }^{(156)}$ Here, the bulls played another role, manifesting the east and the west, and their meeting is the full moon time. The relative position of Apis and Mnevis like two bulls are probably related to this assumption. ${ }^{(157)}$

6- The bull Apis is depicted twice; surmounting the cenotaph, contains the deceased's mummy. One on the antechamber's western wall of Petosiris's tomb at Mazawaka necropolis. The second one is on the southern wall of the burial chamber of Tomb C5 at el-Salamuni necropolis in Akhmim.

Apis was associated with the myth of Osiris. It accompanied Horus while searching for the scattered parts of Osiris's body, and transfer them on his backbone. His accompanying with Horus in searching for his father's body authorizes him as the "companion of the kings" and "the helper god". Hence, Apis was the carrier of Osiris's mummy to Memphis to be embalmed there. ${ }^{(158)}$ Moreover, he was the carrier of the deceased's mummy in "hurried run", the deceased as Osiris, hope Apis to carry him to his tomb in a secured journey to his afterlife (pl. 19). ${ }^{(159)}$

When the bull Apis carried the deceased to his afterlife residence, this imitated the actions of chapter Nr. 162 of the book of the dead, called a spell (for) (proving) (heat under the head of the blessed one) ${ }^{(160)}$ or formula for placing warmth under the head of a transfigured spirit. ${ }^{(161)}$ This is very great protection, which the heavenly Cow used for her son $\mathrm{Re}$ at his site, when his seat was surrounded by ardent troops with kindled faces, by putting this amulet upon the living person's throat, this will be transformed like a flame and fire in his enemies' face, and by locating it around the deceased's throat, he will be divine in the god's domain and shall not be kept from any of the underworld gates. ${ }^{(162)}$

Later, during the mummification, this amulet was put around the mummy's neck. The sky-cow "Ihet" is asking the creator "Atum" to secure the deceased. Here, the name of the creator "Atum" is concealed in an amulet in shape of disk+scarab+old man. The final words and illustration evoke the sky-cow in visual and material terms, as an amulet to be surrounding the wrapped body's neck. During the Late and Ptolemaic period; this amulet was written on metallic, cloth, or cartonnage disks under the mummy's head. These disks are known in Egyptology as hypocephali, originated from the Greek term hypo means "under", and kephalos means "head". ${ }^{(163)}$

The scene where Apis carrying the mummy either depicted on the mummy cartonnage of Berlin 22728, shows the bull Apis while surmounting a shrine in standing position, the deceased (Antinos son of Hierax) in the mummified form, while goddess Maat is crouching, with here two feather-emblem, one upon her head, the other on her knee. ${ }^{(164)}$ Apis carrying the deceased was a basic representation of the book of the dead papyri from Akhmim. Apis is depicted while carrying the deceased in different ways. Such scene is depicted on the "Papyrus of Hor" from Akhmim (BM EA 10479), Apis is crouching upon a shrine, while the deceased in his mummified form is not depicted as usual inside the shrine, but Apis carries him between his two horns (pl.20). ${ }^{(165)}$ An identical scene is illustrated on the Papyri of Mac Gregor, ${ }^{(166)}$ and that of Berlin 10477, both from Akhmim. ${ }^{(167)}$ on the Papyrus of Mac Gregor; Apis was depicted carrying the deceased in a different way, on his backbone(pl.21). ${ }^{(168)}$

Carrying the deceased to the underworld is connected with the heavenly cow, who is accompanying the sun-god in his daily journey in the heaven. every night, he entered the underworld of Osiris, and then resurrected in the morning as a youthful god. The deceased depicts himself in the mummified-form in his tomb, with the help of the sky-cow goddess he will secure a good sending to his afterlife, with neither dangers nor evils. ${ }^{(169)}$

7- On the tomb of Petosiris at el-Mazawaka; the bull Apis and the four sons of Horus are depicted twice. They are shown before Apis in their normal human figures. The existence of the Apis bull with the four sons of Horus is depicted in chapter 148 of the book of the dead. Dating to the Ptolemaic period, Apis is either depicted in the tomb of Iufankhof at Bahariya Oasis. Moreover, the crouching figure of the bull Apis is depicted on Nesmin's Papyrus from Akhmim. ${ }^{(170)}$ Since the $18^{\text {th }}$ dynasty; the four sons of Horus appeared in their human figures in several positions; behind Osiris, protectors for the father-god Osiris, as in spell 17 and 137 of the Book of the Dead, ${ }^{(171)}$ holding the royalty scepters and pieces of clothes, or as worshippers for god Osiris. ${ }^{(172)}$

8- The two Apis bulls adoring the fetish of Abydos are either depicted twice. One is in Petubastis's tomb, exactly on the lower register of the tomb's northern wall, this show the tomb's owner while adoring the two bulls, who are venerating the fetish of Abydos. The other one is in Tomb C3 at Akhmim.

There is a close connection between the two Apis bulls and the fetish of Abydos from the Pharaonic period. ${ }^{(173)}$ This is the illustration of chapter 138 of the Book of the Dead ${ }^{(174)}$ in which the deceased is repeating a formula to enter Abydos and being among Osiris' followers. The deceased is acting as Horus, declares divine status following judgment, and triumphing over enemies in the afterlife. ${ }^{(175)}$ 
Adoration scene is preceded by carrying Petubastis's mummy on chariot by three men and a priest, he is making libation by his right hand, and burning incense by the censer in his left hand. However, the judgment scene of Petubastis is depicted on the wall's upper register before Osiris.

Venit suggested the two bulls are alternatives for Isis and Nephtys, who venerated the fetish of Osiris either. ${ }^{(176)}$ He built his assumption due to the depiction of two uncrowned kneeling females in the eastern half of the southern entrance wall of Petosiris's tomb, a vertical object in a shrine where the sun god is in a falcon's form, and perches as a depiction of the sun rise. ${ }^{(177)}$ Definitely, they resemble Isis and Nephtys (pl.22).

In the funerary house no. 21 of Tuna el-Gebel, Isis and Nephtys are depicted twice in the burial chamber. They appeared in the lunette over the burial chamber's door, with Horus and Anubis, they are revering an aspect of the sun god, ${ }^{(178)}$ and depicted either on the western side of the northern wall venerating the sun disc. ${ }^{(179)}$ The funerary beds which were found in tomb nr.7 of Tuna el-Gebel, entitled as the Pyramid-Tomb. ${ }^{(180)}$ There were representations of two Apis bulls with the sun-disc upon their heads, and the Uraeus on the foreheads are depicted flanking Osiris (pl.23). On the same bed, Isis and Nephtys are flanking Osiris twice, one in the form of Ibis Thot, who was unified with Osiris in the city (pl.24), while the other one depicts Osiris in his normal form(pl.25). ${ }^{(181)}$ moreover, Isis and Nephtys are depicted flanking the Abydos-fetish on another funerary bed, which was uncovered in the same tomb (pl.26). This assumed the two Apis bulls are acting the roles of Isis and Nephtys as guardians for Osiris.

9- Scenes of the deceased while making direct offerings before the bull Apis occurred three times in Akhmim tombs. One scene exists upon the rear wall of the burial chamber's niche of tomb IV. The second scene is on the left side of the burial chamber's northern wall in tomb C3. The third scene is on the southern wall of the burial chamber of tomb C5. The deceased in white robe is semi-damaged to know the kinds of offerings he presents, and an altar before him.

The offerings and libations before the bull Apis is a major scene on the Papyri of the book of the dead tradition from Akhmim, can be seen on Nesmin's papyrus, where the deceased is making libations with his right hand, and burning incense with his right hand. ${ }^{(182)}$ In addition, on the papyrus of Hor; the deceased is making a libation with his left hand upon a very lower altar. ${ }^{(183)}$ The same scene is depicted on P. Hildesheim 5248 from Akhmim, where the female deceased is raising her hands in adoration attitude before the bull Apis, who is wearing the menat-collar and an altar in between. ${ }^{(184)}$

Furthermore, the offering before the bull Apis was extant several times outside Egypt. Of these, at Mensa Isiaca of Rome, a priest is offering two Egyptian cups before Apis, and an altar is between (pl. 27). ${ }^{(185)}$ Another sample is on an obsidian cup from Stabia, ${ }^{(186)}$ where a man is making offering with his left hand, and making libation with his right hand before Apis in his Egyptian shrine. Besides a female figure; probably Isis; holding a scepter in her right hand behind Apis as a kind of protection, related to her role as a guardian for Osiris (pl. 28).

\section{Plates}

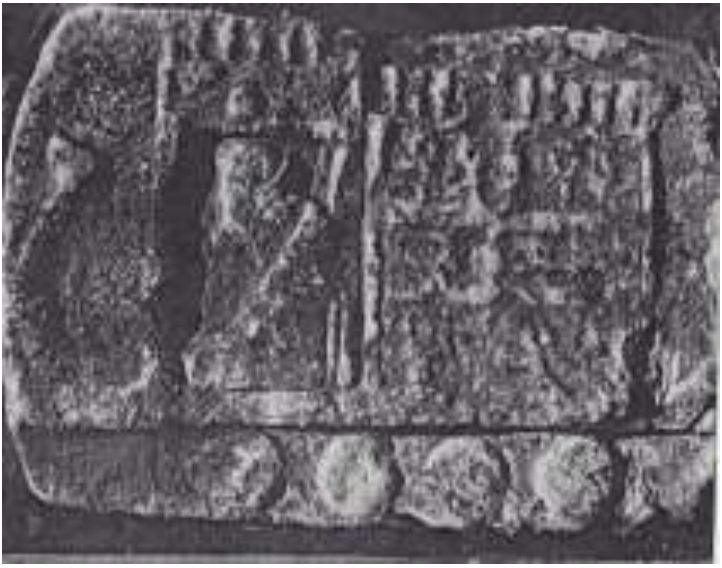

Pl. 1(A). The wheeled barque of Apis

Petrie, F., Roman Portraits and Memphis (IV), pl. XXX

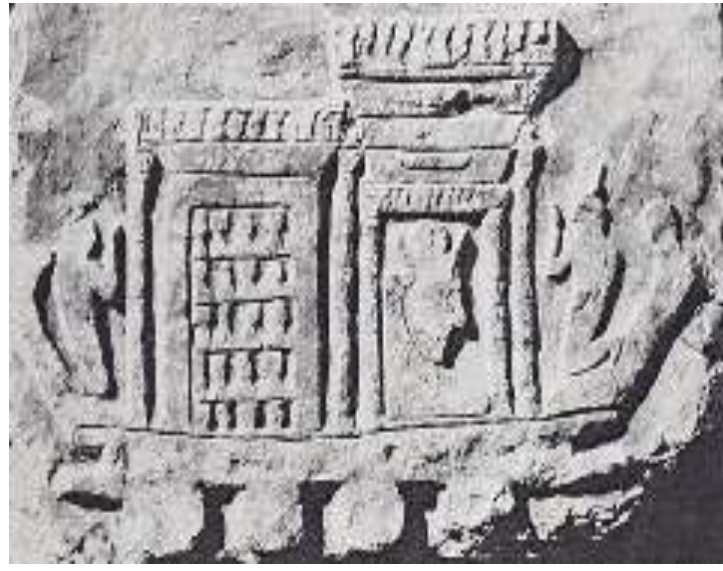

Pl. 1(B)The Apis catafalque Farag, S., Two Serapeum Stelae, JEA (61), p.164, No.2 

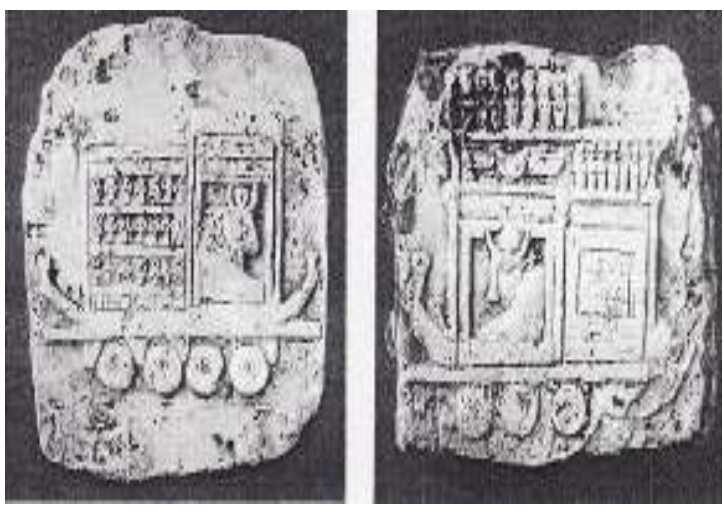

Pl. 1(C) El Amir, M., JEA (34), pl. XVII

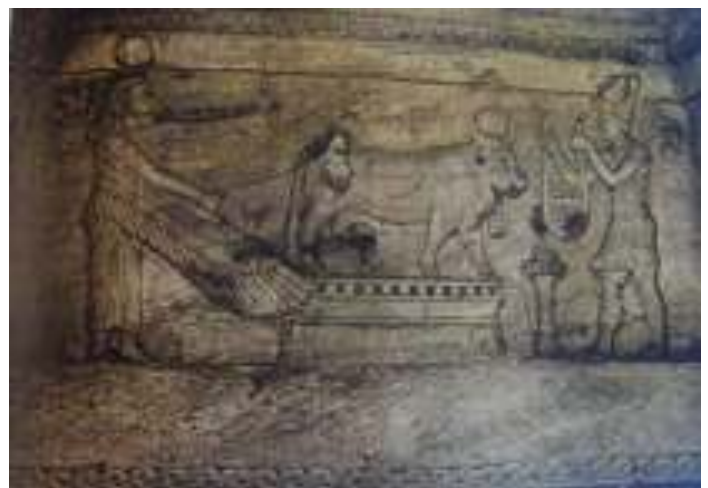

Pl. 3. The left niche- Kom el- Schukafa

Kaplan, I., Grabmalerei und Grabreliefs der Römerzeit, pl. 36 (a)

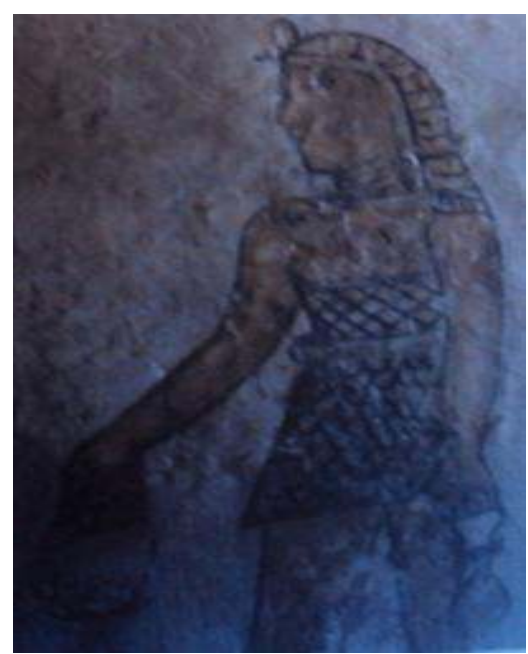

Pl.4 (C).Tigrain's tomb

Kaplan, I., Grabmalerei und Grabreliefs der Römerzeit, pl. 51 (b)

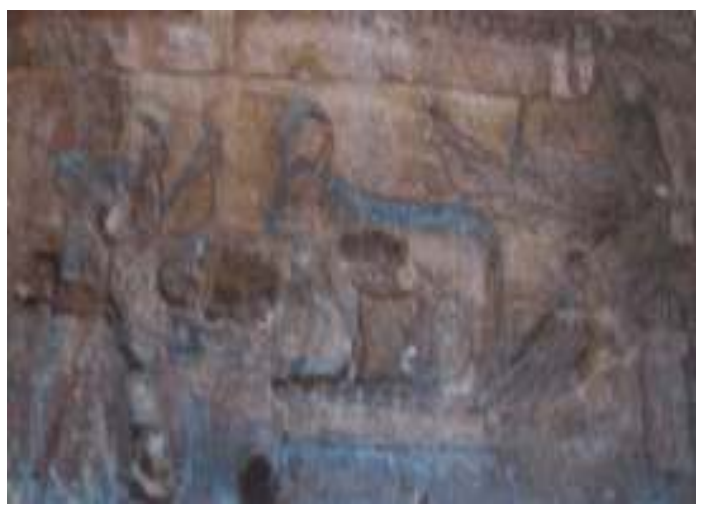

Pl. 2 The right niche- Kom el-Schukafa Ibid, pl.35 (a)

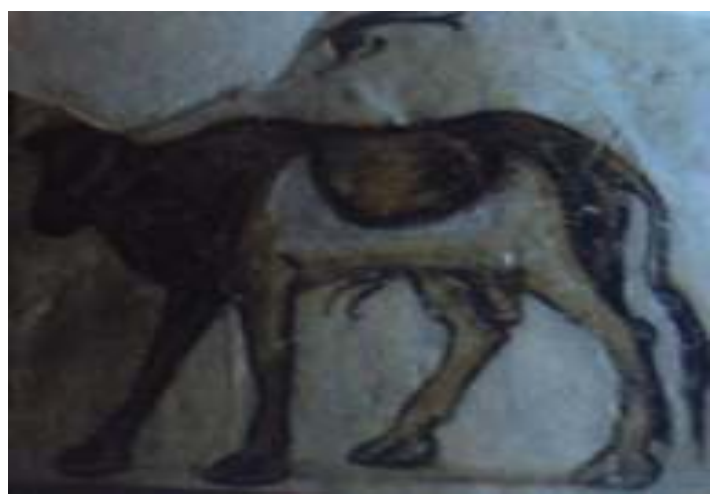

Pl.4 (B).Tigrain's tomb

Kaplan, I., Grabmalerei und Grabreliefs der Römerzeit, pl. 51 (a)

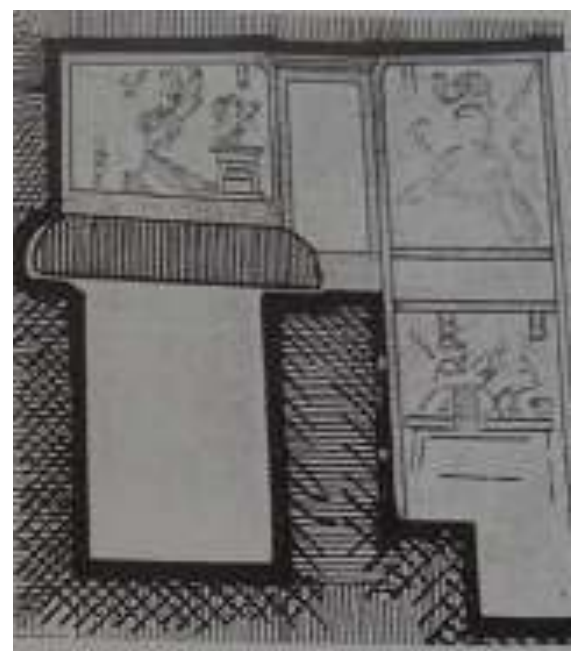

P1.5 Qabbari Tomb A- Habachi Tomb Kaplan, I., Op. Cit, pl.61 (b) 


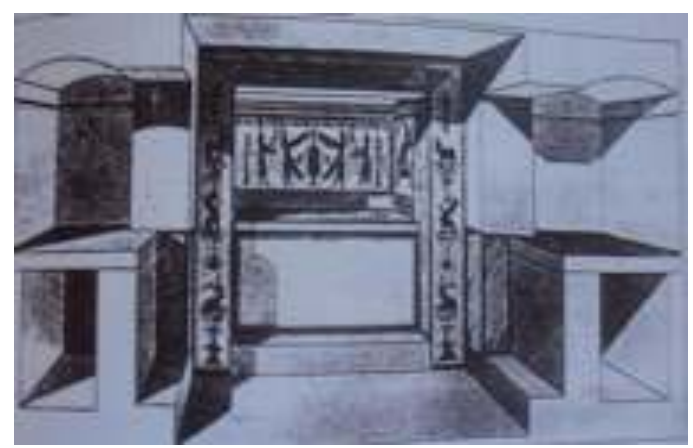

P1. 6 Sieglien Tomb-Qabbari

Pagenstecher, R., Nekropolis. Untersuchnungen, Leipzig, 1919, fig.10

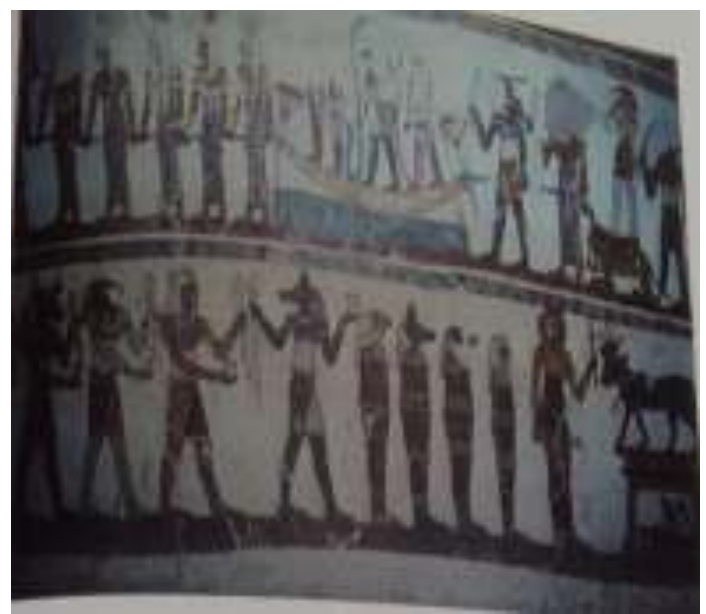

P1.8 Petosiris tomb- el-Mazawaka Ibid, pl. 106 (a)

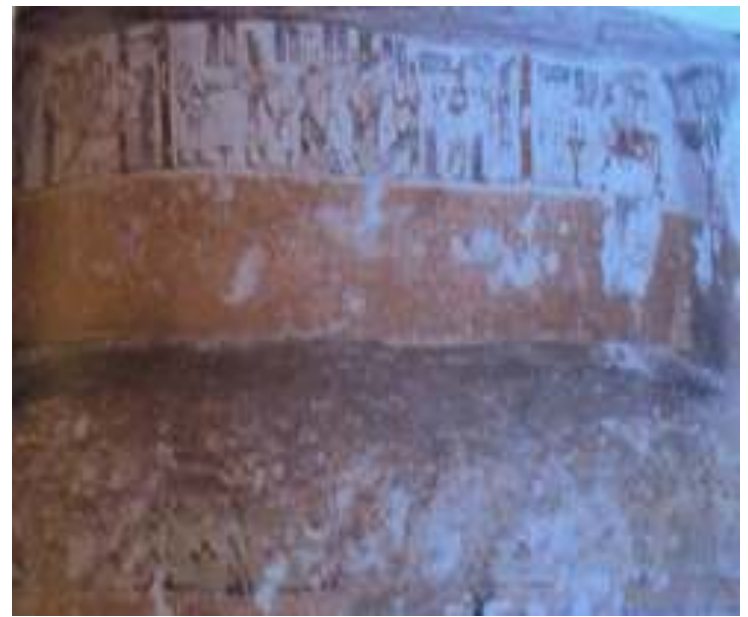

Pl. 10 The niche of the burial chamber- tomb IVAkhmim

Kkaplan, I., Grabmalerei , pl. 93 a

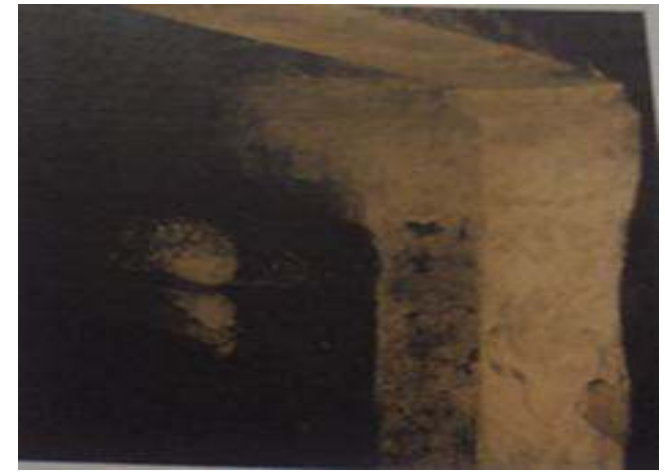

P1.7 Minet el-Basl plaster-decoration Kaplan, I., Op. Cit, pl.71 (b)

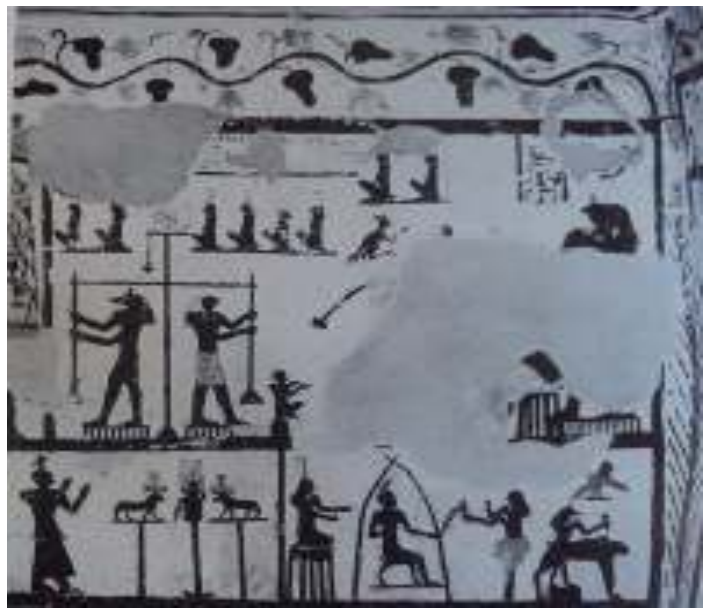

Pl.9 Petubastis Tomb

Osing, G.,Denkmäler der Oase Dachla, pl.26 (c)

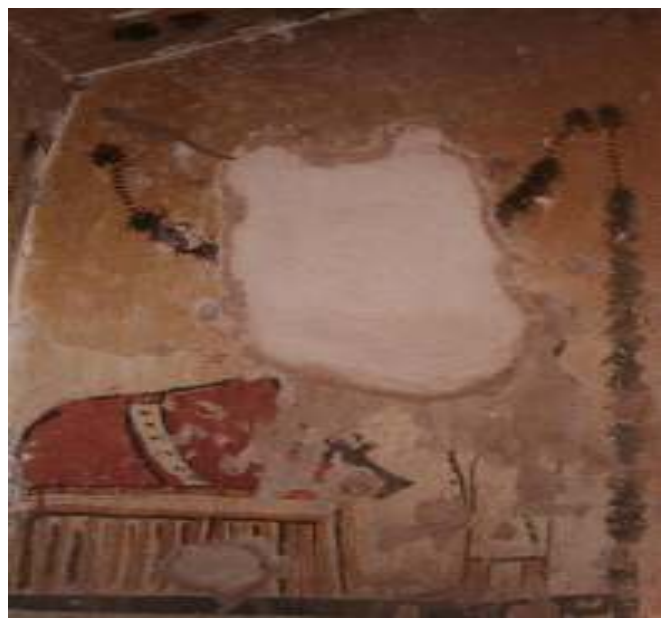

Pl. 11 Tomb C3-Akhmim, the researcher's photo 


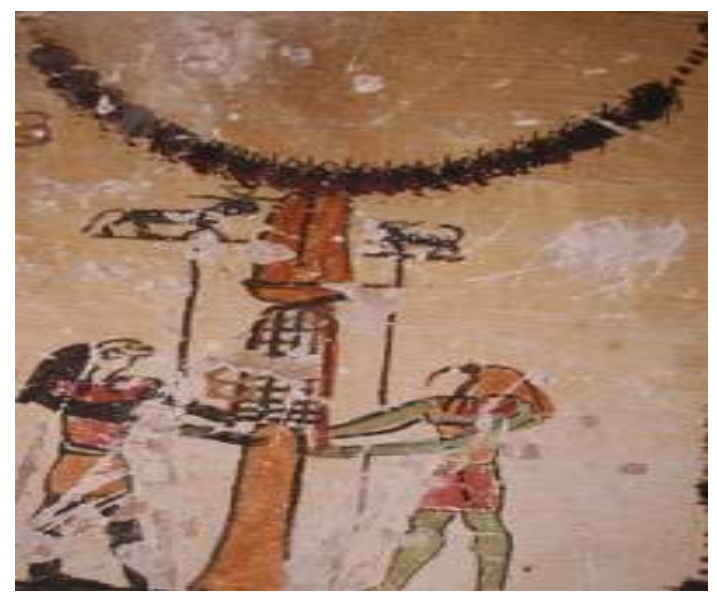

Pl.12 Tomb C3- Akhmim, the researcher's photo

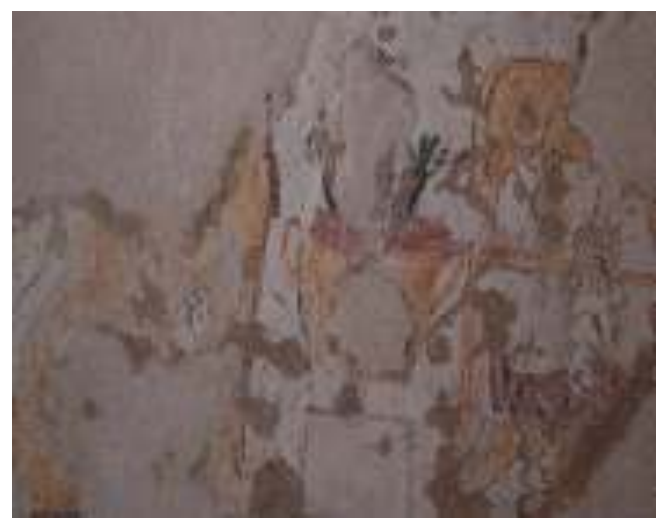

Pl.13 (B) Tomb C5- Akhmim, the researcher's photo

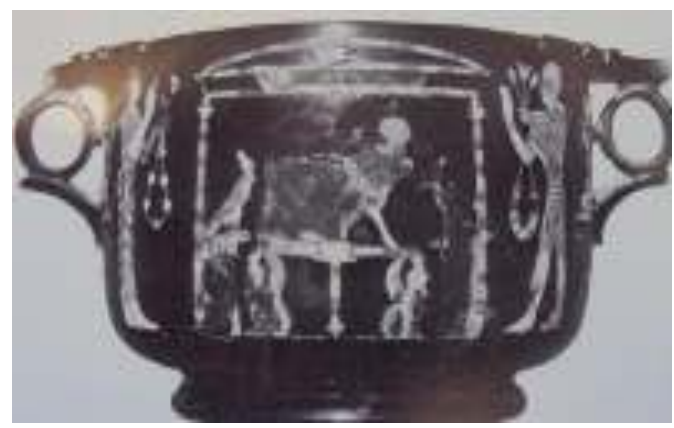

Pl.15 (A) an obsidian cup from Stabiai Malaise, Inventaire Préliminaire des Documents Egyptiens découverts en Italie, EPRO (21), Leiden, 1972, pl.54

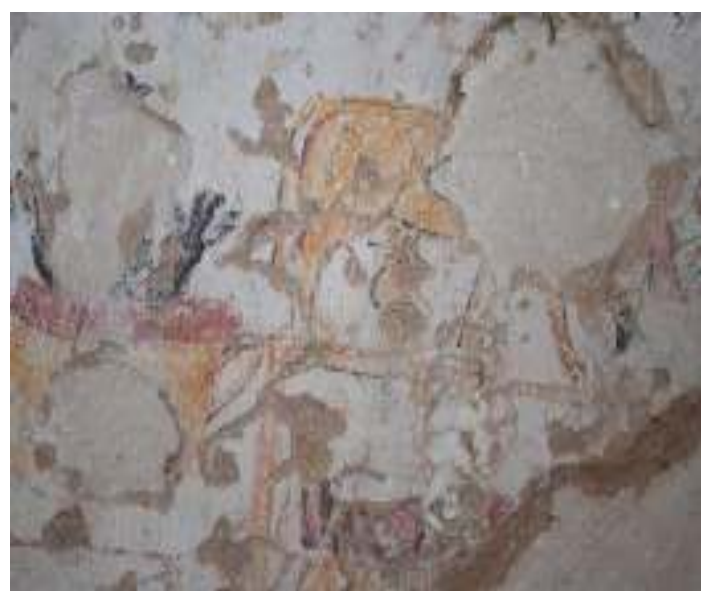

Pl. 13 (A) Tomb C5- Akhmim, the researcher's photo

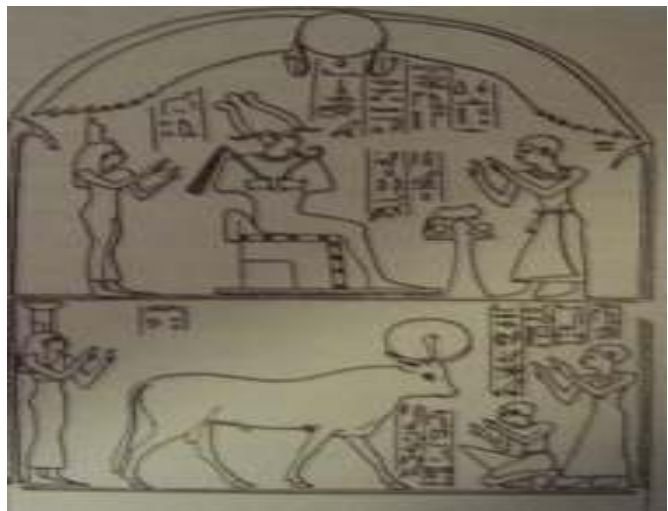

Pl.14 Stela of Imhotep, Ptolemaic period, Imhotep adores Osiris and Apis- Berlin Mus.7304

Erman, A., Die Religion der Ägypter, Ihr Werden und Vergehen in Vier Jahrtausenden, New York, 2001, pp.384-385, fig. 157

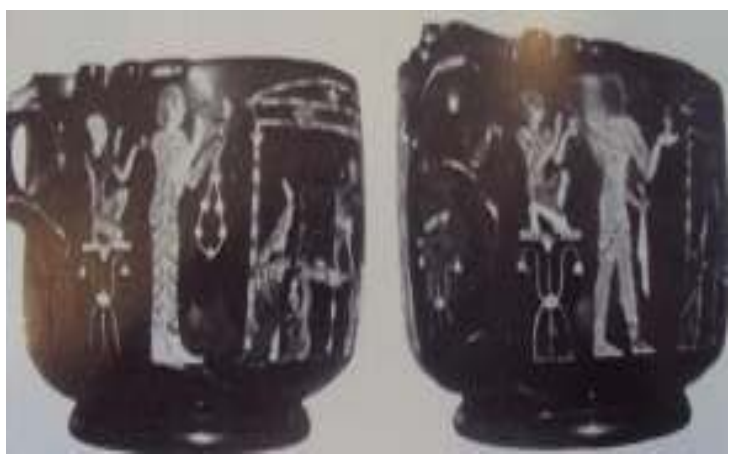

Pl.15 (B) The other side of the obsidian cup from Stabiai, Ibid, pl.54 


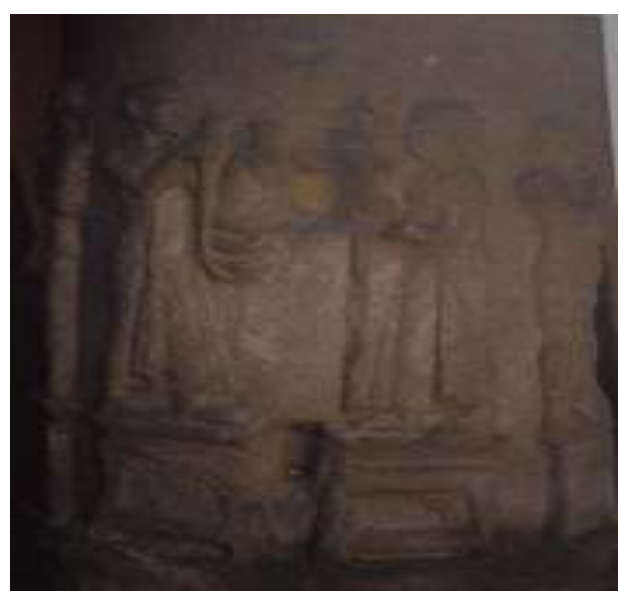

Pl. 16 Offering the Menat-Collar to the Priest of Isis- A column of the Iseum Campense Kaplan, I., Op. Cit, pl. 17 (a)

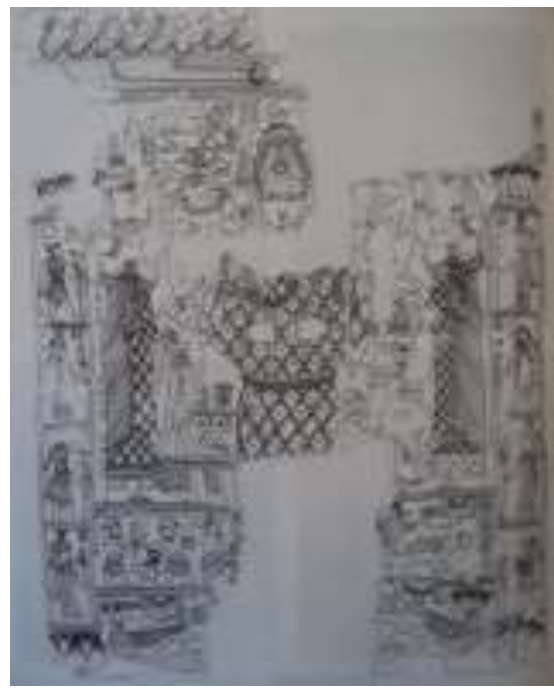

Pl.18 The shroud of Bocchoris

Whitehouse, H., " Sacred Bovids: An unusal Terracotta Statuette from Roman Egypt", in: Sitting beside Lepsius, fig.2

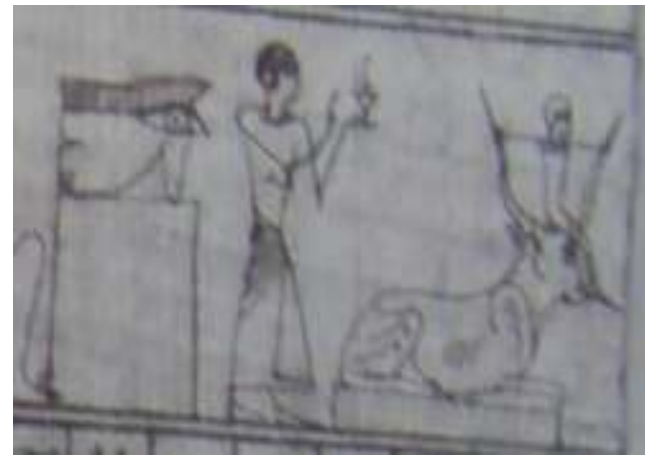

Pl.20 P. BM 10479- Akhmim

Mosher, M., Op. Cit, pl. 3, frame 10

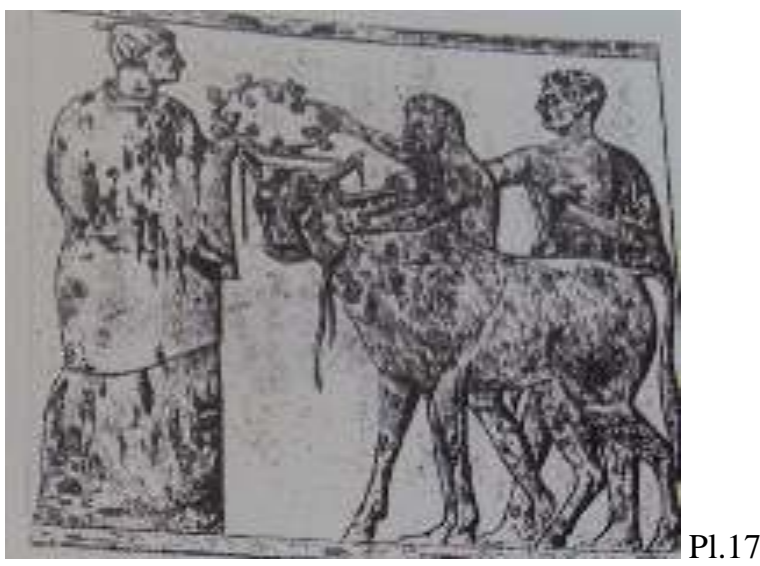

Petosiris Tomb-Tuna el-Gebel

Lefebvre, G., Le Tombeau de Petosiris, Troisième Partie, Vocabulaire et Planches, IFAO, Le Caire, pl. XIX

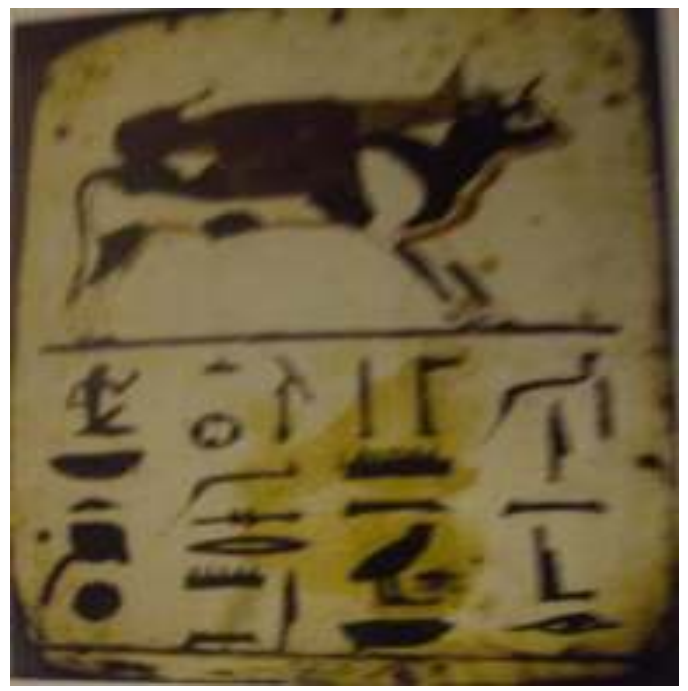

Pl.19 The carrying of the Deceased by Apis Peppler, J., " Der Kult des Apis", in: Kemet (2012/3), 2012, p. 43, fig.5

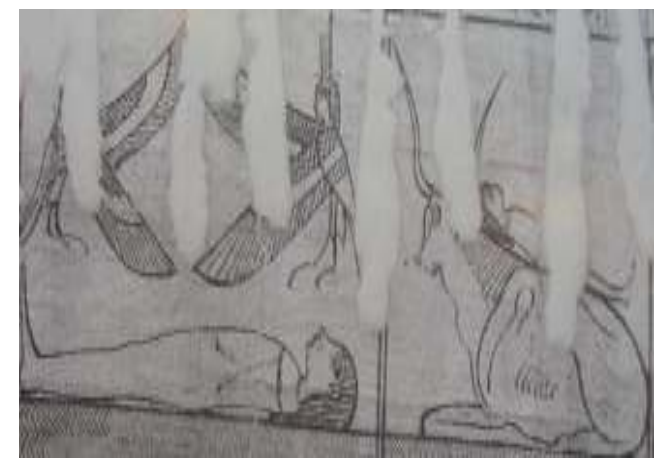

Pl. 21 P.Mac Gregor- Akhmim

Mosher, M., The papyrus of Hor (BM EA 10479), with Papyrus McGregor, pl. 17.1, frame 9 


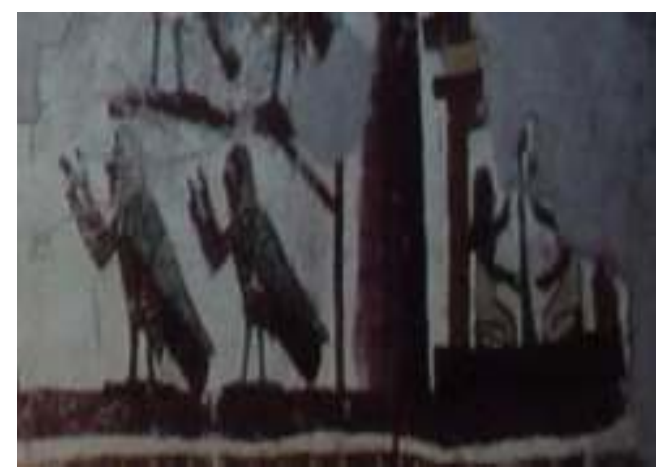

P1.22 Isis and Nephtys are erecting the Fetish of Abydos- Petosiris Tomb

Kaplan, I., Op. Cit, fig. 106 (b)

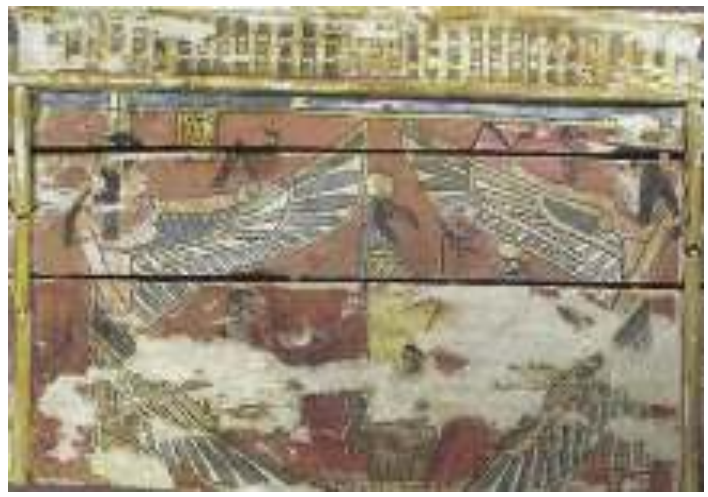

Pl.24 The Pyramid tomb-Tuna el-Gebel Ibid, pl. VII

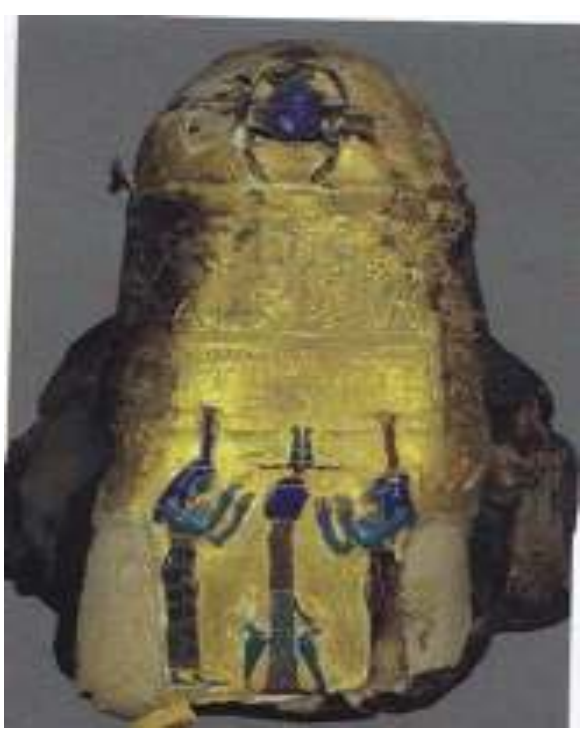

Pl. 26The Pyramid tomb-Tuna el-Gebel Ibid, pl. XXII

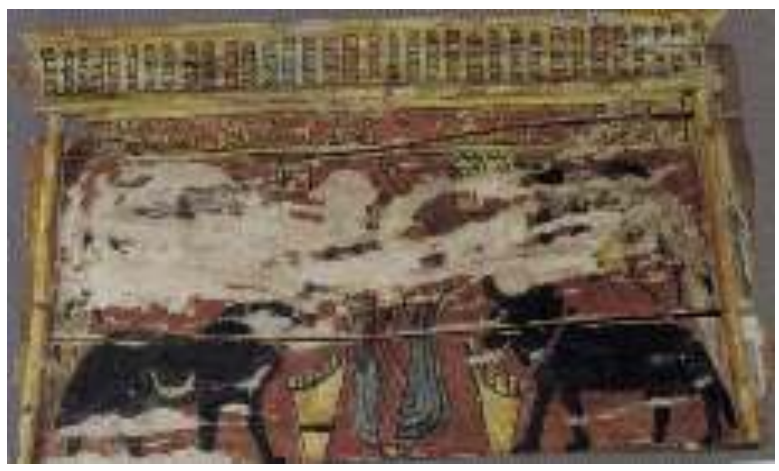

Pl.23 The Pyramid tomb-Tuna el-Gebel Flossmann, M and Schütze, A., Ein Römerzeitliches Pyramidengrab und seine Ausstattung in Tuna elGebel, pl. VIII

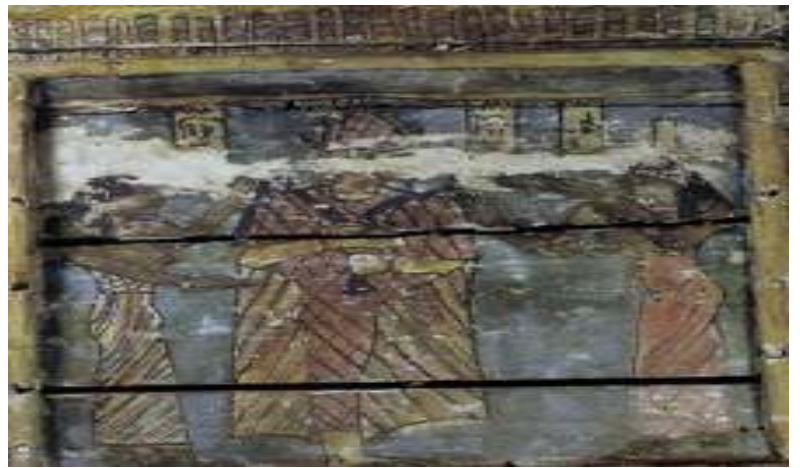

P1.25 The Pyramid tomb-Tuna el-Gebel Ibid, pl. IX

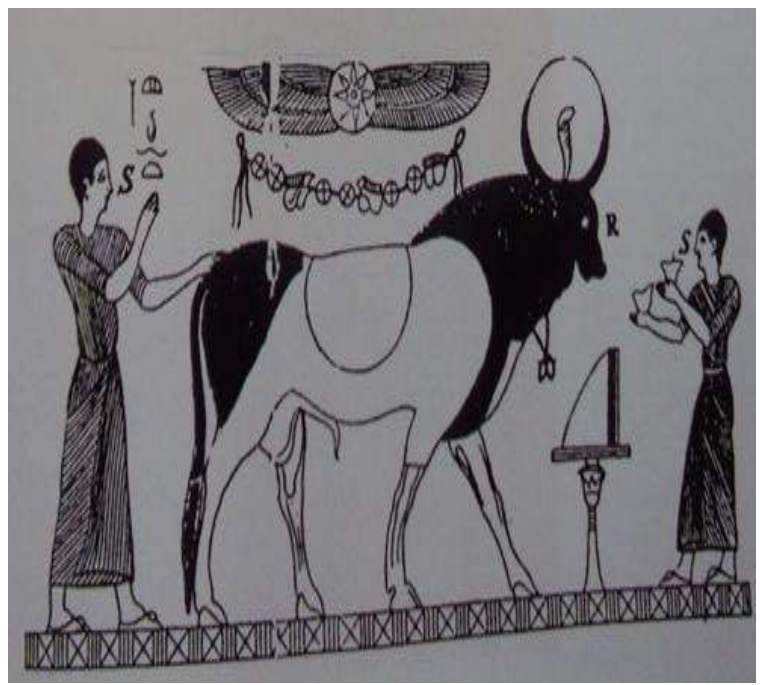

Pl. 27 Mensa Isiaca

Kaplan, I., Op. Cit, pl. 17 (B) 


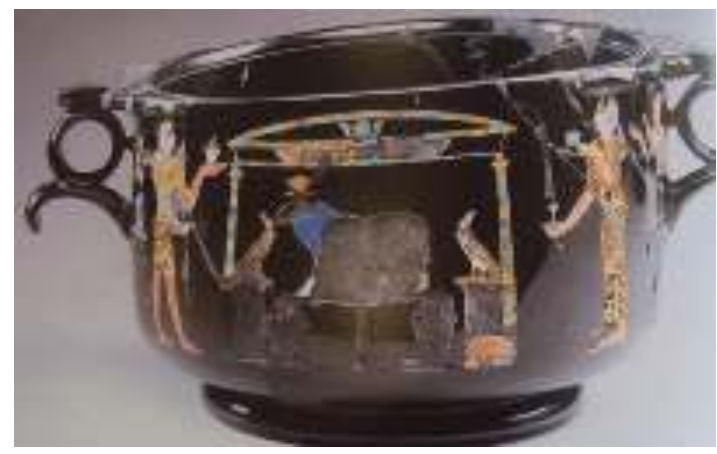

Pl.28 Cup at Naples

Alfano, C., "Egyptian Influence in Italy", in:

Cleopatra of Egypt from History to Myth, p. 284, fig.9.5

\section{تصوير العجل أبيس في المقابر اليونانية الرومانية في مصر}

انتشرت عبادة العجول فى مصر خلال العصر اليونانى_الرومانى لاسيما عبادة العجل أبيس. تعتبر منف هي المركز الرئيسى لعبادة أبيس،

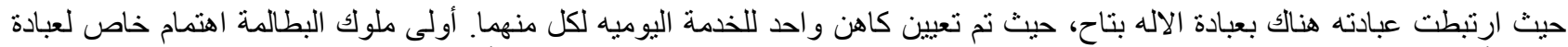

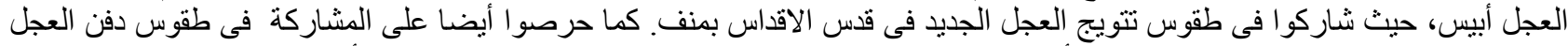

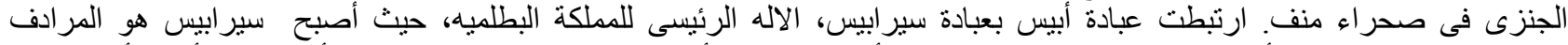

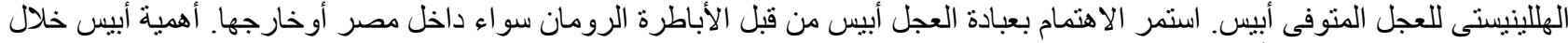

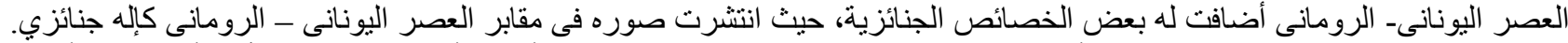

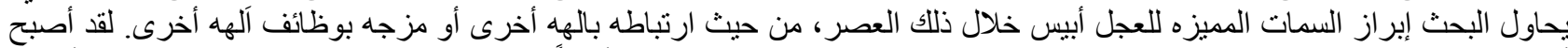

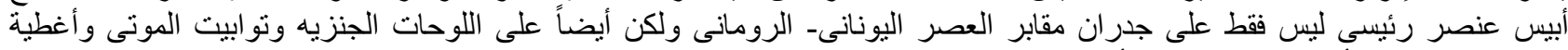

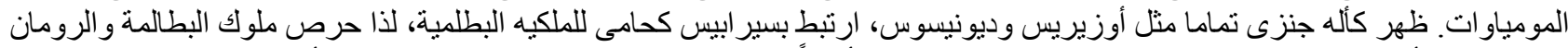

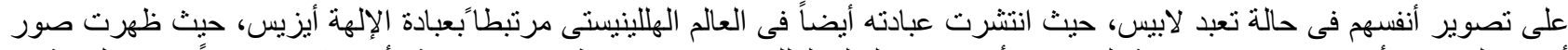

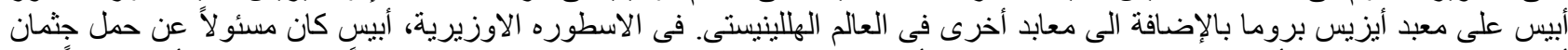

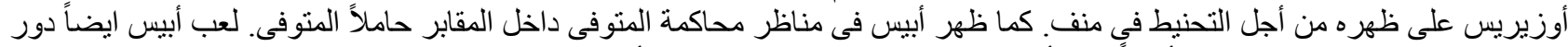
ايزيس ونفتيس كحامى لاوزيريس و أيضاً رمز أبيدوس من خلي خلايل ظهور شكلين للإله أبيس. الكلمات الدالة: العجل أبيس - عبادة ـ العصر اليونانىـ الرومانى - سير ابيس- منفــ أوزير -ابيس

\section{Endnotes}

1. About the history of the worship of bulls in Egypt see Otto, E., Beiträge zur Geschichte in Agypten, in: Untersuchungen zur Geschichte und Altertumskunde Aegyptus (13), Leipzig, 1938,pp.11-34; Bonnet, H., Reallexikon der Ägyptischen Religiongeschichte, Berlin, 1952, pp.46-51. Apis, pp. 751-753

2. Simpson, W., "A running of the Apis in the Reign of ${ }^{c}$ Aha and passages in Manetho and Aelian", in: Orientalia (26), 1957, pp. 139-142

3. Otto, E., Op. Cit, pp. 11-14

4. Thompson, D., Memphis under the Ptolemies, Princeton, 1988, p. 191

5. Ibid, pp. 196-197

6. Sethe, K., Hieroglyphische Unkunden der Griechisch- römischen Zeit, Historisch- Biographische Urkunden aus der Zeit der Makedonischen Könige und Urkunden des Ägyptischen Altertums (ed. By Steindorff, G), UrK(II); Leipzig, 19041916

7. Mariette, A., Memoir sur la mere d'Apis, Paris, 1856; id., Le Serapeum de Memphis, Paris, 1857; Maspero, G., Le Serapeum de Memphis par August Mariette-Pacha, Paris, 1882; Lauer, J., Saqqara, the Royal Cemetery of Memphis, London, 1976, pp. 11-28, 217-224

8. Lauer, J., Saqqara, the Royal Cemetery of Memphis: Excavations and Discoveries since 1850, London, 1976, p.25; Emery, W., "Preliminary Report on the Excavation at North Saqqara", in: JEA (57), 1971, pl. VI (2). Herodoute referred that Psammeticus I built a courtyard for the Apis, surrounded by 12 cubits high colossi playing the role of columns. Herod. II, 53

9. Vercoutter, J., Textes Biographiques du Serapeum de Memphis: Contribution a l'Etude des Stèles Votives du Serapeum. Bibliothèque de l'Ecole des Hautes Etudes, $4^{\text {th }}$ Section, Paris, 1962, p.26.

${ }^{10}$. Hepnebes is a large area close to the Ibis galleries, is a demotic ostraca archive of Hor/ Harthot preserve numerous details of the complex including courts and a tower. Thompson, D., Memphis under the Ptolemies, p.30 
11. Thompson, D., Op. Cit, p. 192; For more information see: Smith, H., " Dates of the Obsequies of the Mothers of Apis", in: $\operatorname{RdE}(24), 1972$, pp. 176-187; Davies, S et al., The Sacred Animal Necropolis at North Saqqara, the Mother of Apis and Baboon Catacombs, the Archaeological Report, Seventy- Sixth Excavation Memoir, EES, London, 2006

12. Burials are attested as early as the life time of king Amenhotep III. Devauchelle, D., "Osiris, Apis, Sarapiset les Autres, Remarques sur les Osiris Memphites au Ier Millénaire av. J.C", in: Le Cult d' Osiris au Ier Millenium AV.J.C. Découvertes et Travaux Recents, Actes de la table ronde Internation etenue a Lyon Maison de l'orient et de la Méditerranée (Universite Lumiere- Lyon2) les 8 et 9 Juillet 2005. (ed. By Coulon, L), IFAO, Cairo, 2010, p. 51. Kaplan, I., Grabmalerei und Grabreliefs der Römerzeit, Wechselwirkung zwischen der Ägyptischen und GriechischAlexandrinischen Kunst, Band(16), Vienna ,1999, p. 81. While the subterranean galleries for burials of Apis bulls were begun during the reign of Ramses II at Saqqara. The serapeum of Memphis was built during the $26^{\text {th }}$ dynasty, and by the $30^{\text {th }}$ dynasty there were 134 sphinxes in place along the Serapeum as processional way. Bommas, M., "Isis, Osiris, and Serapis", in: The Oxford Handbook of Roman Egypt, (ed.By Riggs, C), Oxford, 2012, p.422. The burial vaults of Apis of the serapieion were closed after Cleopatra' bull, but the burials continued but not discovered yet.

13. Ellis, W., Ptolemy of Egypt, London, 1994, p.62, Osiris also was identified with Dionysos see De Iside et Osirid, 13, 356 AB, Hani, J., La Religion Egyptienne dans La Pensee de Plutarque, Paris, 1976, pp.166-181 and also assimilated with Adonis, Ibid, pp.51, 65, 66,70, 77, 78

${ }^{14}$. Dunand, F., " Un Dieu Nouveau, La "Creation " de Serapis", in: Hommes et Dieux en Egypte (300 a.c -395 p.c), (ed.by Dunand, F and Zivie- Coche, C), Paris, 2006, p. 286, Heydo, S., The Cult of Isis among Women in the Graeco-Roman World, Leiden, 1975, p.3

${ }^{15}$. Quack, J., " Serapis als neuer Gefährte der Isis, von der Geburt eines Gottes aus dem Geist eines Stier", in: Imperium der Götter, Isis. Mithras. Christus, Kult und Religionen im Römischen Reich, Karlsruhe, 2013, pp.165-166. Despite Plutarch's description of Ptolemy I Soter's dream (De Iside et Osiride. 28), in which the colossal statue of Pluto of Sinope exhorts the king to transport him to Alexandria, Scholars relate Serapis's origin with the connection of the Egyptian god, the dead Osiris, and the sacred died Apis bull of Memphis.

16. The Ptolemies seek to create a dyad with Egyptian and Greek pantheons, by making Serapis, the consort of Isis, the main deity of Alexandria, being a god without myth. Bommas, M., Op. Cit, p. 422

17. Stambaugh, J., Serapis under the Early Ptolemies, in: EPRO(25), Leiden, 1972, p.36, Stiehl, R., "The Origin of the Cult of Serapis", in: History of Religions (3), 1963/1964, pp.21-36, about Serapis see: Bouche-Leclerq., "La Politique Religieuse de Ptolemee Soter et La Culte de Serapis", in: RHP (46), 1902, pp.1-30

18 . Pfeifer, S., "The God Serapis, his Cult and the Beginnings of the ruler Cult in Ptolemaic Period", in: Ptolemy II and his World, (ed. by. M $^{\mathrm{c}}$ kechnie, P and Guillaume, P), Leiden, 2008, p.391

19 . Heinen, H., " Ägyptische Tierkulte und ihre hellenischen Protektoren. Überlegungen zum Asylieverfahren SB III 6154 (= IG Fay. II 135) aus dem jahre 69 v. Chr", in: Vom hellenistischen Osten zum römischen Westen, Ausgewählte Schriften zur Alten Geschichte, Stuttgart, 2006, pp. 146-147

20. The figure of Serapis was presented to the Greeks in human figure, not an animal. Greek sculptor "Braxis" is credited with devising the statue of the god, and images show Serapis as a bearded deity, with a remarkable attribute of a kalathos, or basket on his head, and his hair addressed similar to Hades with strands hanging down onto his forehead. Venit, M., " Alexandria", in: the Oxford Handbook of the Roman Egypt, Oxford, 2012, p. 113

21. Diodorus mentioned; an Apis bull died during the lifetime of Ptolemy I. He did not only paid for the high costs of the ritual ceremony of Apis, but also advanced 50 talents towards additional expenditure. Diod, I,84. All the Ptolemies paid more attention for the cult of the bull Apis at Memphis who associated with their coronations. See Crawford, D.,"Ptolemy, Ptah and Apis in Hellenistic Memphis", in: Studia Hellenistica (24), Lovan, 1980, pp. 10-18, Hornbostel, W., Sarapis, Studien zur Überlieferungsgeschichte, Den Erscheinungformen und Wandlungen der Gestalt Eines Gottes, EPRO (25), Leiden, 1975, p.150

${ }^{22}$. Ellis, W., Ptolemy of Egypt, New York, 1994, pp. 30-32. Ammianus Marcellinus ranks the Serapeum of Alexandria second only to the Capitolium in Rome. Ammianus. Marc. 22.16.12. The Ptolemaic Serapeum of Ptolemy II and III stood until a fire in 181 A.D, which also claimed the temple of Harpocrates. Then the temple was rebuilt between 181 and 217 A.D. M $^{\mathrm{c}}$ kenzie, J et al., "Reconstruction the Serapeum in Alexandria from the Archaeological Events", in: JRS (94), 2004, pp. 73-121, and remains till the final destruction in the late $4^{\text {th }}$ century A.D by Theophilus. Venit, M.," Alexandria" in the Oxford Handbook of Roman Egypt, p. 114. The destruction of the Serapeum in 391 A.D must also have an end to the worship of the Apis bull. But the Apis bull appeared later in a poem by Claudian dates back to the Christian Emperor Honrius in Rome, this poet was born in Egypt, the poem in Latin, referring to a procession for Apis bull in Memphis. Hemelrijk, E. and Smelik, K ," Who knows Not What Monsters Demented Egyptian Worship", in: ANRW (17,4), 1984, pp. 1980-1981. A magnificent basalt statue of Apis bull was found in the galleries of what is called "the library of Alexandria", it dates back to the reign of Hadrian, now in the Graeco- Roman museum of Alexandria. About the Serapeum of Alexandria see: Sabottka, M., Das Serapeum in Alexandria, Untersuchungen zur Architektur und Baugeschichte des Heiligtumes von der Frühen Ptolemäischen Zeit bis zur Zerstörung $391 \mathrm{n}$. Chr, in: Etudes Alexandries (15), Cairo, IFAO; 2008, pp. 215-218, 477- 481. The Apis bull was certainly worshipped in the Serapeum of Alexandria but in a separate shrine. Wace, A., Greek Inscriptions from the Serapeum, in: Bulletin of the 
Faculty of Farouk I University (Alexandria), II, 1944, p.21, n.2; Stambaugh, J., Sarapis under the Early Ptolemies, Leiden, 1972, pp. 65-66.

23. There were 42 Sarapieia or temples of Serapis in Egypt. See Höpfner, Th., Fontes Historiae Religionis Aegyptiacae, Bonn, 1922, p. 306; Behr, Ch., P. Aelius Aristides. The Complete Works, II, Leyde, 1981, p.268

${ }^{24}$. P.Oxy. 3239, II, 31f

${ }^{25}$. Morenz, S., "Das Problem des Werdens zu Osiris in der Griechisch- Römischen Zeit Ägypten”, in: Religions en Égypte hellénistique et romaine: colloque de Strasbourg, 16-18 Mai, 1967, (ed. by Derchain, P), Paris: Presses universitaires de France, 1969, p. 86

${ }^{26}$. Later in the Roman period, the oracle of Bes was the main figure at Abydos. Sayce, A., "Some Greek Graffiti from Abydos", in: PSBA (10), 1887, p.283, Crum, W., "Coptic Graffiti", in: The Osireion of Abydos, (ed. by Murray, M), in: BSAE (9), London, 1904; Rutherford, I.,"Pilgrimage in Greco-Roman Egypt: New Perspectives on Graffiti from The Memnonion at Abydos", in: Ancient Perspectives on Egypt, (ed.by Matthews, R and Roemer, C), London, 200; Kornmann, W.,"NeuesÜber die Phönikischen und Aramäischen Graffiti in den Tempeln von Abydos", in: Anzeiger der PhiosophischenHistorische Klasse der Öster, Akademie der Wissenschaft (115),1978; -Delattre, A., Les Graffitis CoptecD'Abydos et La Crue du Nile", in: Cahiers de la Bibliotheque Copte (13), Paris, 2003; Crum, W., "Coptic Graffiti", in: The Osireion of Abydos, (ed. by Murray, M), in: BSAE (9), London, 1904. About the connection between Serapis and Osiris, see: Fraser, P., "Two Studies on the Cult of Serapis in the Hellenistic World", in: OpsculaAtheniensia (3), Lund, 1960, pp.1-54, Stiehl, R., "The Origin of The Cult of Serapis", in: History of Religions (3), 1963-1964, pp.21-33; 1904.

${ }^{27}$. Diod. I, 25, 2; Plutarch. De Iside et Osiride, $354 \mathrm{~F}^{3}$

28. According to Herodotous the deified Apis bull has special characteristics as basically black in color, with double hairs to his tail, a white square on his brow, an eagle on his flank, and a scarab under his tongue, inverted white triangle on the forehead, the Horos falcon stretched over its flanks, and a vulture a cross the shoulders, juidicious touching-up with paint might help on special occasions. The Apis bull lives beside the sources of the Nile as a standard ingredient of classical accounts of the land of Egypt. Herod. 3. 28.3

29. P. Cornell 1.8. The high priest of Ptah was the chief religious representative of the city and when the synods of priests of all Egypt during the Ptolemaic period met in Memphis was under the auspices of Ptah temple, where the Ptolemaic king was crowned. Crawford, D.,Stud. Hellen.(24), , p. 23

${ }^{30}$. Louvre stele 4246 ; Brugsch, H., Der Apis- Kreis aus den Zeiten der Ptolemäer nach den hieroglyphischen und demotischen Weihinschriften des Serapeums von Memphis, in: ZÄS (24), 1886, p. 26. The high priest was responsible also from the reign of Epiphanes for crowning the Ptolemy at Memphis. Crawford, D., Stud. Hellen. (24), p. 18

${ }^{31}$. See Kucharek, A., Altägyptische Totenliturgien, Die Klagelieder von Isis und Nephtys in Texten der GriechischRömischen Zeit, Band (4), Heidelberg, 2010, p. 591

32. The embalming house (hw.t qbh) lies in the southern western quarter of the temple of Ptah. The identification of the embalming house is conclusively made by Vercoutter, J., Textes Biographiques du Serapeum de Memphis, Paris, 1962, pp.55-58, Dimick, J., "The Embalming House of the Apis Bulls", in: Archaeology (11), 1958, pp.183-189 . The details of the inhumation of the bull Apis was inscribed in ademotic papyri. See: Voss, R., The Apis Embalming Ritual, P. Vindob. 3873, OLA (50), 1993; Hoffmann, F., "Boebkbesprekingen: The Apis embalming ritual", in: BiOr (52), 1995, pp. 581-589. Pierre Meyrat suggested that the place of embalming the Apis was not related to the embalming of the bull, but that it was a place where priests would purify themselves by a ritual bath and by shaving before starting the embalming operation, Meyrat, P., "Topography- related problems in the Apis Embalming Ritual", in: Ägyptische Rituale der griechisch- römischen Zeit, in: Orientalische Religionen in der Antike (6), Tübingen, 2014

${ }^{33}$. Petrie,F., Roman Portraits and Memphis (IV), British School of Archaeology, London, 1911, p.24, pl. XXXI; Farag, S., "Two Serapeum Stelae", in: JEA (61), pp.165-166, pl. XXIII (1).

${ }^{34}$. Voss considered this lake as Lake of Abusir. Voss, Op. Cit, p.159.Meyrat disagreed, that he suggested it as "southwestern lake", as Lake Abusir was probably situated far to the north-west of the Place of Embalming . Meyrat, P., "Topography- related problems in the Apis Embalming Ritual", in: Ägyptische Rituale der griechisch- römischen Zeit, in: Orientalische Religionen in der Antike (6), Tübingen, 2014, pp.254-255, see maps in Thompson, D., Op. Cit, 11 and $22 \mathrm{f}$

35. A Greek papyri of Ptolemaios archive of Memphis from the Serapeum mentioned a dramatic ritual ceremony for a dead Apisbul in $6^{\text {th }}$ April 164 B.C the bull's death age is 22 years, 2 months and 23 days. Two Egyptian twin sisters named as Taousand Thaues mourned the Apis bull in the show. See. Brugsch, H., in: ZÄS (22), pp.125-126; Wilcken, U., UPZ I, 18, 46-47, II, 8-9, 20-21, 23-25. About the twins and the bull see: Thompson, D., Op. Cit, pp. 233-244

${ }^{36}$. Thompson, D., Op. Cit, pp.198-203.

${ }^{37}$. Ibid, p. 201

38. The so-called Apis papyrus. Vienna No. 27 gives complete details of the mummification of the dead bull during the $26^{\text {th }}$ Dyn. About the Apis Papyrus see: Spiegelberg, W.," Ein Bruchstück des Bestattungsrituals des Apisstier (Demot.Pap. Wien Nr. 27", in: ZÄS (56), pp.1-33

39. Crawford, D., Stud.Hellen. (24), p. 9

${ }^{40}$. Meyrat, P., Op. Cit, p. 258

${ }^{41}$. Ray, J., "The House of Osorapis", in: Man, Settlement and Urbanism, (ed. by Ucko, P et al), 1972, London, p. 699 
42 . Peppler, J., " Der Kult des Apis", in: Kemet (2012/ 3), 2012, p. 43

43. Diod. I.96.7-9, Thompson, D., Op. Cit, pp. 202-203

44 . Bommas, M., Op. Cit, p.422

45 . Smith, H., " The Saqqara Papyri: Oracle Questions, Pleas and Letters", in: Acts of the Seventh International Conference of Demotic Studies, (ed.by Ryholt, K), Copenhagen 23-27 August 1999, Copenhagen, 2002, pp. 367-375.About Apis bull's connection with oracles. Frankfurter, D., Religion in Roman Egypt, New Jersey, 1998, pp.148, 150. At Kysis (Dusch) at Dachla oasis, numerous small gold ex-voto medallions portraying both Isis and the Apis bull that the town's temple was a center of oracle by visitors who are seeking incubation and health. Ibid, p. 47

46. Diod, I.84.6; Strabo, 17.1.31

47 . see: Courcella, P., "L'Oracle d' Apis et l'OraclejuJardin de Milan(Augustin, Conf. VIII II, 29), in: Revue de l'Histoire des Religions (139), 1951, pp.216-231

48 . P.Ross. Georg. 5.19 (236 A.D); Thompson, D., Op. Cit, p. 274

49 . Kessler, D., "Das Hellenistische Serapeum in Alexandria und Ägypten in Ägyptologischer Sicht", in: Ägypten under der Östliche Mittelmeerraum im 1. JahreTausend v. Chr.(ed. byGörg, M and Hölbl, G), Wiesbaden, 2000, pp.170-172, fig.1

${ }^{50}$. Thompson, D., Op. Cit, p. 274

${ }^{51}$. Wilcken, U., Urkunden der Ptolemäerzeit (ältere Frunde), II, Papyri aus Oberägypten, Berlin, 1957, p.33

52 . Thompson, D., Op. Cit, p. 254; Karter-Sibbes, G and Vermaseren, J., Apis, I, The Monuments of the Hellenistic- Roman Period from Egypt, EPRO (48), Leiden, 1975, p.26, pl. LXII, 92

53. Many oracles were connected in the site with the sacred animal necropolis of Saqqara, that oracles and dreams formed part of the spiritual life connected with these cults, the visitors came to interpretation their dreams or asking for health and medical help. Especially there was an Asklepieion in the site and alarge deposit of anatomical casts of Ptolemaic date found in the area behind the temple terrace of the sacred animal necropolis and similar dedications within the upper baboon galleries may be for Imhotep's cult at Memphis. Sauneron, S., " Les Songs et leur Interpretation, Paris, 1959, pp.40-53; Lang, P., Medicine and Society in Ptolemaic Egypt, Leiden- Boston, 2013, pp.56-57

${ }^{54}$. Guilmot, M., "Le Sarapieion de Memphis, Etude Topographique", in: CE (37), 1962, p.372; Ray, J., Op. Cit, pp.701-702

55. Cartron, G., L'architectureet les PratiquesfunerairesdansL'Egypte romaine, BAR (2298.2), Oxford, 2012, p. 80; Alan Rowe suggested him as a pharaoh. Rowe, A., " Excavations of the Graeco- Roman Museum at Kom el-Schukafaduring the Season 1941-1942", in: BSAA (35), 1942, p. 23

56. Venit, M., Monumental Tombs of Ancient Alexandria, the Theater of the Dead, Cambridge University Press, 2002, pp. 138-139. Kaplan, I., Op. Cit, p. 82, fig. 35( a), 36 (a); Castiglione, L., "Kunst und Gesellschaft im Römischen Ägypten“, in: Acta Antiqua, Academiae scientiarum Hungaricae (15), Budapest, 1967, p.124, p. 124, pl. XIII (1)

57. Kater-Sibbes, G and Vermaseren, J., Op. Cit, pl. LXII (93)

58. Kaplan, I., Op. Cit, p. 82, fig.50 (b), 51 (a)

${ }^{59}$. Kater-Sibbes, G and Vermaseren, J., Op. Cit, p. 27, pl. LXIV(97)

60. Tomb A excavated in the modern Alexandria quarter of Qabbari by BanoubHabachi in 1935, dates back to the early Roman period. Habachi, B., " Two Tombs of the Roman Epoch Recently Discovered at Gabbary, in: BSAA (31), 1937, pp. 270-285; Adriani, A., Repertoriod'artedell'Egitto Greco- Romano 1, Serie C, Palerme, 1966, p.159, pl. 84, fig. 279; Cartron, G., L., Op. Cit, pp. 52-54

61. Venit, M.,Monumental Tombs , p. 120

${ }^{62}$. Kapln, I., Op. Cit, p. 82, fig. 62 (a). The Sieglin tomb discovered at Gabbari in 1900 during the first Sieglin expedition, the tomb is known only from a drawing by Doctor- Engineer Ernst R. Fiechter, who was one of the architects along with August Thiersch of the Sieglin Expedition during the excavations at Kom el-Schukafa . The tomb illustrates the power of Egyptian signs and themes in the period of Roman rule. Venit, M., Op. Cit, pp. 124-125; Rowe, A., " Excavations of the Graeco- Roman Museum at Kom el-Schukafaduring the Season 1941-1942", in: BSAA (35), 1942, p. XV

63. Venit, M., Op. Cit, p. 109, fig.102; Cartron, G., Op. Cit, p. 51, fig. 109; Kapln, I., Op. Cit, pp. 147-148, fig. 62(a)

64. The tomb was excavated by Adriani in 1950/1951. It combines Greek and Egyptian elements, Greek architectural elements and Egyptian iconographic signs. Adriani, A.,"Scavi e ScoperteAlessandrine (1949- 1952), C. NuoveScopertenellaNecropoliOccidentale", in: BSAA (41), 1956, pp. 17-33. Tomb A contains two large niches; the east one contains a rock-cut sarcophagus with a sloping lid, while the western one contains a kline-sarcophagus with a mattress. Venit, M., Op. Cit, p.97

65. Adriani, A., Op. Cit, p.21; Kapln, I., Op. Cit, p. 83; Venit, M., Op. Cit, p. 97; Tkaczow, B., The Topography of Ancient Alexandria (an Alexandria Map), Varsovie, 1993, p.60

66. About the tomb see: Von Bissing, F., "Funde in Ägypten", in: JDAI (16), 1901, p.58; Adriani, A., Repertoriod'artedell'Egitto Greco- Romano I, Serie C, Palerme, 1966, p.32, 180, fig.39

67. Kaplan, I., Op. Cit, p.83; Habachi, L., "Occasional Archaeological Discoveries reported to the Graeco- Roman Museum in 1941-1942”, in: BSAA (35), 1942, p. 109

${ }^{68}$. Kaplan, I., Op. Cit, p. 150; Cartron, G., Op. Cit, p. 39; Adriani, A., Repertoriod'artedell'Egitto, p.32, 180, fig.39

69. Osing, J etal., Denkmäler der Oase Dachla, Aus dem Nachlass von Ahmed Fakhry, Archäologische Veröffentlichungen (28), Mainz, 1982, p. 83, fig 26 (a). This kind of necklace appeared as a collar on the neck of goddess Mehurt, the eye 
of Re as a cow on the western wall of the tomb of SI- Amon at Siwa. Fakhry, A., The Egyptian Deserts, Siwa Oasis, its History and Antiquities, Cairo, 1944, p. 145, fig. 25

${ }^{70}$. Osing, J., Op. Cit, pls. 21 (b) and 24 (c); Lembke, K et al., Ägyptens spat Blüte, Die Römer am Nile, Mainz, 2004, p. 71, fig.127; Venit, M., " Referencing Isis in Tombs of Graeco- Roman Egypt: Tradition and Innovation", in: Isis on the Nile, Egyptian Gods in Hellenistic and Roman Egypt, Proceedings of the IV ${ }^{\text {th }}$ International Conference of Isis Studies, Liege, November 27-29 2008, (ed. By. Bricault, L and Versluys, M), EPRO (171), Leiden, 2010, p. 97

${ }^{71}$. It was numbered by Kapln as Tomb IV. fig. 91 (a)- 95(b); Kuhlmann, K., MaterialienzurArchäologie und Geschichte des Raumes von Achmim, in :SDAIK(11), Mainz,1983, pl.38 (a)

${ }^{72}$. See: Abbas, E., The Lake of Knives and the Lake of Fire, Studies in the topography of passage in ancient Egyptian literature, BAR International Series (2144), Oxford, 2010

73. A stela was found at Memphis of the $2^{\text {nd }}$ century B.C, shows Apis standing beside an altar, accompanied by an inscription that alludes to the interpretation of dreams. Edgar, C., Greek Sculpture (CGC, Nos. 27425-27630), Cairo, 1903.

${ }^{74}$. Guilmot, M., Le Sarapieion de Memphis. Etude Topographique", in: CdE (37), 1962, pp.365-366

75 . Diodorus described women's ritual involvement with the new Apis bull, during his stay in his barque with a gilded cabin. He still forty days at Nilopolis before his final installation in the temple of Ptah at Memphis. In Nilopolis, only women has a permission to look to the Apis bull, they stand, facing him, and pulling up their clothes, display their genitals, but after this they are prevented from ever coming into the presence of the god a gain. He is connected with pregnancy and the apotropaic effects on women. Diod.I, 85. Montserrat, D., Sex and Society in Graeco- Roman Egypt, London, 1996, p.167. Frankfurter, D., Religion in Roman Egypt, p. 104. Marriette excavated a full-size statue of an Apis bull at Saqqara in 1851, where local childless women spontaneously gathered to straddle the statue's back, may the bull's fertility might be imparted to them. Maspero, G., Le Serapeum de Memphis, p.30; Montserrat, D., Op. Cit, pp. 167-168

76. Malaise, M., " La Diffusion des Cultesisiaques, Un Probleme de termnologie et de critique", in: Nile into Tiber, Egypt in the Roman World, Proceedings of the $3^{\text {rd }}$ International Conference of Isis Studies, Leiden, May 11-14 2005, (ed. by Bricault, L, Versluys, M and Meyboom, P), EPRO (159),2007, p.23

77. About the connection between Serapis and Dionysos see Stambaugh, J., Sarapis under the Early Ptolemies, pp. 55-59

78. Malaise, M., Op. Cit, p. 23

79. Ibid, p. 23. He was connected with monuments inside the Isiac sanctuaries outside Egypt such as the Iseum of Campense. See:Lembke, L., "Das Iseum Campense in Rom. Studien über den Isiskult unter Domitian“, in: Archäologie un Geschichte (3), Heidelberg, 1994, pp. 113, 174-176, pl. 3. Also in the Iseum of Pompeii. See: Karter-Sibbes, G and Vermaseren, J., Apis, I, p.299, pl. LIV; V. a crouching figure of Apis connected with Isis cult at Cologne. See: KarterSibbes, G and Vermaseren, J., Apis II, Monuments from outside Egypt, $\mathrm{n}^{\circ}$ 350, pl. XCII; Haase, M., "Kulte der Isis in den germanischen Provinzen", in: Isis en Occident, p. 133, n.7. Many bronze statues for Apis in his grouching or moving attitude with his two horns and the solar-disc were found in many places outside Egypt. Malaise, M., Op. Cit, pp. 23-24

${ }^{80}$. Brugsch, H., "Eine geographische Studie", in: ZÄS (17/ 1), 1879, p. $19 \mathrm{f}$

81. Apis was connected also with the moon. See Kucharek, A., Altägyptische Totenliturgien, Die Klagelieder von Isis und Nephtys in Texten der Griechisch- Römischen Zeit, Band (4), Heidelberg, 2010, p. 138

82. Chassinat, E., Textes Provenant du Serapeum de Memphis, Paris, 1901, p. 79

83. A stela in Berlin Museum nr. 7304 of Graeco-Roman Period, depict the owner is adoring Osiris, and Isis behind him, in the upper register of the stela, while two men are adoring the Apis bull and Isis behind in the lower register. See : Erman, A., Die Religion der Ägypter, Ihr Werden und Vergehen in Vier Jahrtausenden, New York, 2001, pp.384-385, fig. 157

${ }^{84}$. About the mother of Apis galleries see: Davies, S. et al, The Sacred Animal Necropolis at North- Saqqara, the Mother of Apis and Baboon Catacombs, the Archaeological Report, EM (76), London, 2006; Smith, H et al., The sacred animal necropolis at North Saqqara: the mother of Apis inscriptions, Texts from Excavations 14. London: Egypt Exploration Society", in: JEA(99), 332-334; id.," The sacred animal necropolis at North Saqqara: the mother of Apis inscriptions, Texts from excavations 14. London: Egypt Exploration Society ", in: JARCE (48), 261-262; Kessler, D., Die heiligen Tiere und der Könige, Teil. 1: Beiträge zu Organisation, Kult und Theologie der Spätzetlichen Tierfriedhöfte, in: ÄAT (16), Wiesbaden, 1989, p.97..

${ }^{85}$. Many figurines of Apis was found with statuettes of Isis- Hathor. Wessetzky, V., "Remarques sur les Représentations d'Isis- Hathora l' Epoque Romaine", in: Hommages a Jean Leclant, Vol (3), Etudes Isiaques, IFAO, 1994, pp. 491-492. A terracotta from the temple of Sokenbtynis depicts Hathor is suckling the young calf. Rondot, V., Le Temple de Soknebtynis, et son Dromos, Tebtynis II, FIFAO (50), Le Caire, 2004, p.50; id., Derniers Visages des Dieux d'Egypte, Iconographies, Pantheons et Cultes dans le Fayoum hellénise des II III $^{\mathrm{e}}$ Siecles de Notre Ere, Paris, 2013, p. 255

${ }^{86}$. The nick name of the mother of Apis in Saqqara was $\mathrm{t} 3 \mathrm{hr}$. see: Kessler, D.,Die heiligen Tiere und der Könige, p.97; Brugsch, H., Op. Cit, in: ZÄS (24), 1886, p.23; Peppler, J., Op. Cit, (Kemet 2012/ 3), p. 45

${ }^{87}$. Urk. IV, 328; Peppler, J., Op. Cit, pp.45-46

${ }^{88}$. Laskowska-Kusztal,E., " Le pered'Amenhotep: HapououApis?", in: Et.Trav.(13), 1984, pp.215-220 
${ }^{89}$. See Turcan, R., The Cults of the Roman Empire, Translated by Antonia Nevill, Oxford, 1996, pp. 85-90

90. Since Virgile, The Romans opposed the animal -cult of the Egyptians, and considered these gods as monsters. Dunand, F., " Problèmes et Controverses", in: , in: Hommes et Dieux en Egypte, p. 351

91 . Suetonius, Vespasian VI, 3

92 . Henrichs, A., "Vespasian's Visit to Alexandria", in: ZPE (3), 1968, pp. 51-88

93. Tacitus. Historia IV. 82; Suetonius, Vespasian VII.I

${ }^{94}$. Tacitus. Historia IV. 81; Suetonius, Vespasian VII.2; Dio Cassius 6.8.1

95. Two fragments from Asia Minor, related to Roman official is called "Mucianus", he was with Vespasian in Egypt, and returned to Rome via Rhodes. Williamson, G., " Mucianus and a Touch of the Miraculous: Pilgrimage and Tourism in Roman Asia Minor", in: in: Pilgrimage in Graeco- Roman \&Early Christian Antiquity, Seeing the Gods, Oxford University Press, 2005, p.235

96. Dunand, F., Isis, Mère des Dieux, Paris, 2000, p. 122. Later many Roman Emperors paid attention to the bulls' cults of Egypt, especially for Apis and Buchis. Though the founder of the Roman imperial Augustus, refused the veneration of the Apis bull, he refused to present offerings to Apis, saying that he would make offerings to gods, but not to beasts. Dio Cassius. 51. 16.5; Herklotz, F., "AegyptoCapta, Augustus and the Annexation of Egypt", in: The Oxford Handbook of Roman Egypt, p. 13; Stadler, M., "Egyptian Cult, Evidence from Temple Scriptoria and Christian Hagiographies", in: Oxford Handbook of Roman Egypt, p. 457. Though Hadrian depicted himself with the head of Apis on his coins, see Von Bissing, F., "Eine Apis figure in der Haltung der Adlocutio", in: Oriental Studies Dedicated to Paul Haupt, (ed. by Adler, C and Ember, A), Baltimore: Johns Hopkins University Press, p. 298. He visited the Apis bull at Memphis during his visit to Alexandria. Dunand, F., " Croyances et RituelsFunerairs, Les Images de l'Au-Dela: Vision Egyptienne et Vision Grecque", in: Hommes et Dieux en Egypte, p. 420: Many Roman Emperors were depicted in the form of Egyptian gods as Horus, Anubis, Harpocrates, Tutu, and Bes. See: Tallet, G and Zivie-Coche, C., "Imported Cults", in: The Oxford Handbook of Roman Egypt, pp. 446-447. Diocletian has a stela depicts himself in the homage of the Buchis bull, dates back to 288 A.D. Dunand, F., " Croyances et Rituels Funerairs, Les Images de l'Au-Dela: Vision Egyptienne et Vision Grecque", in: Hommes et Dieux en Egypte, p. 420

97. it was suggested that his act had subversive overtones. Suetonius, Tit, 5.3; Herklotz, F., Prinzeps und Pharao: Der Kult des Augustus in Ägypten, Frankfurt am Main, 2007, pp. 297-298. The Diadem was a symbol of kingship in the Hellenistic period. See:Ritter, H., Diadem und Königscherrschaft, Uuntersuchnung zu Zeremonien und Rechtschgrundlagen des Herrschafsantritts bei den Persern, bei Alexander dem Großen und im Hellenismus, Vestigia, Beiträge zur Alten Geschichte (7), München,1965

98. He did not obtain the official confirmation of the Senate and the Romans before the end of December, after Vitellius had been defeated and killed. Henrichs, A., Op. Cit", pp. 51-52

99. Venit, M., Op. Cit, pp. 142-143.

100. The Port of Memphis lies down on the Nile to the east of the Ptah temple and the area known as the city frontage, the proasteion, this was an active center of the city's economic life, and though the foundation of Alexandria may have effected its role. During the Roman period Memphis served the northern villages of the Arsinoite nome, where a new Roman tax sheds some light on the cargoes transported overland and shipped through the city. Paid the Fayoum customs houses of Dionysias, SoknopaiouNesos, Karanis, Bakchias, Philopator (also called Theogonis), Philadephia, the tax of Memphis harbor was both on livestock (generally imported camels) and on what these camels and donkeys carried through these posts. See: Thompson, D., Op. Cit, pp. 59-65

101 . P.Coll. Youtie 54 (late $2^{\text {nd }}$ century A. D), P. Mert. 15.5 (114 A.D); Thompson, D., Op. Cit, pp. 207-208

102. Kater-Sibbes, G and Vermaseren, J., Apis, I, p.26

${ }_{103}$. Malaise, M.., Les Conditions de Penetration et de diffusion des cultes Egyptiens en Italie, EPRO (22), Leiden, 1972, pp.413-414

104. Pfeiffer, S., Der römische Kaiser und das Land am Nil, Kaiserverehrung und Kaiserkult in Alexandria und Ägypten von Augustus bis Caracalla (30 v. Chr.- 217n. Chr.), Historiariften Einzelsch(212), Stuttgart, 2010, p.120

105. Thompson, D., Op. Cit, p.273

106 . Suetonius, Tit, 5.3

${ }_{107}$. Kaplan,I., Op. Cit, p.105. In one of the mummy-case at Budapest, the deceased is depicting himself as a king, wears the atef crown of Osiris, and his name in a cartouche. Kurth, D., Der Sarg der Teüris, Eine Studie zum Totenglauben im römerzeitlichen Ägypten, Aeg Trev (6), Mainz am Rhein, 1990, p. 62, fig.20

${ }^{108}$. Cartron, G., Op. Cit, p. 82

109. Von Bissing, F., la Catacombe nouvellement decouverte de Kom el Chougafa, Munich, 1901, p.3; id "Zu den grieschish-ägyptischen Darstellungen", in: Expedition von Sieglin. Die Nekropole von Kom-esch-Shukafa, Leipzig, 1908 , p. 147

110. Kaplan, I., Op. Cit, p. 133, note. 598

111 . Bernand, E., Alexandrie la Grand, $3^{\text {rd }}$ ed. Paris, 1998, p.188

112 . Botti, G., " Mémoire sur les Catacombes de Kom-el-Chougafa", in: in: Expédition von Sieglin. Die Nécropole von Kom-esch-Shukafa, Leipzig, 1908, p. 355

${ }^{113}$. Empereur, J., A Short Guide to the Catacombs of Kom el Schoqafa, Alexandria, Alexandria, 1995, p.7 
${ }^{114}$. Schreiber, Th., "Die Formen der Alexandrinischen Leichenbehälter", in: in: Expedition von Sieglin. Die Nekropole von Kom-esch-Shukafa, Leipzig, 1908, p.262

115. Lembke, K et al., Ägyptens spät Blüte, Die Römer am Nil, Mainz am Rhein, 2004, p. 55

${ }^{116}$. Cartron, G., Op. Cit, p. 83

117. El-Fakharani, F., " Semi-Dome Decoration in the Graeco- Roman Egypt", in: AJA (69), 1965, p. 62

${ }^{118}$. Rowe, A., " Excavations of the Graeco- Roman Museum at Kom el-Schukafa during the Season 1941-1942", in: BSAA (35), 1942, p.10

119. Adriani, A., Repertorio d 'arte dell'Egitto Greco- Romano I, Serie C, Palerme, 1966, p.174

${ }^{120}$. Fraser, P., Ptolemaic Alexandria, Vol (2), Notes, Oxford, 1972, pp. 107-108, note, 262

${ }^{121}$. Bricault, L., "Isis a Rome", in: De Cybele a Isis, Cybele, 2011, p. 147

122. For more information about Vespasian's visit to Alexandria see: For more information about Vespasian's visit to Alexandria: Pfeiffer, S., Der römische Kaiser, pp. 108-119; Henrichs, A., Op. Cit, pp. 51-82

${ }^{123}$. see: Francocci, S.," L' Iseum et Serapeum du Champ de Mars: remarques sur les monuments égyptiens". In: L'Égypte à Rome: actes du colloque de Caen des 28-30 septembre 2002, (ed. by Lecocq, Françoise) Caen: Maison de la recherche en sciences humaines, 2005, pp.187-199; Vendries, C., " Les musiciens figuré ssur les colonnes de l'Iseum du Champ de Mars: une image fidèle de la musique égyptienne? "In: L'Égypte à Rome, pp.383-398

124. Dunand, F., Isis, Mère de Dieux, p. 122

125. Malaise, M., " La Diffusion des Cultes isiaques, Un Problème de terminologie et de critique", EPRO (159), p.23; Pirelli, R., " Il Culto di Iside a Benevento", in: Egittomania, Iside e il Mistero, Milano, 2006, pp.131-132

126. Möller, G., "Das Hb-Sd des Osiris, nach Sargdarstellungen des neuen Reiches, in: ZÄS (39), 1901, pp.71-75, pls. 4-5

${ }^{127}$. Quaegebeur, J., "Apis et la Menat", in: BSFE (98), Octobre 1983, pp. 17-39

${ }^{128}$. Kaplan, I., Op. Cit, p. 105

129. The cup now in Naples Museo Archaeological 312; sporintendenza Archeologica della provincie di Napoli e Caserta Archivio dell'Arte Pedicin. It was found in villa di San Marco in Stabia at 1954. About this cup see: De Caro, S., Egittomania, Iside e ilMistero, Milano, 2006, pp.212-214, Malaise, M., Inventaire Preliminaire des Documents Egyptiens decouverts en Italie, EPRO (21), Leiden, 1972, pl.54; Kapln, I., Op. Cit, p.84, fig. 16(c)

${ }^{130}$. Ibid, fig. 17(a)

${ }^{131}$. Kapln, I., Op. Cit, p. 84

132. Quirke, S., Going out in Daylight, Prt m hrw, the Ancient Egyptian Book of the Dead, Translation, Sources, Meaning, London, 2013, p. 388

${ }^{133}$. Lefebvre, G., Le Tombeau de Petosiris, Troisième Partie, Vocabulaire et Planches, IFAO, Le Caire, pl. XIX

${ }^{134}$. During the Roman period, the situla always in the right hand of the deceased and takes a number of forms and serves a number of functions. See: Lichtheim, M., " Situla n. 11395 and Some Remarks on Egyptian Situlae", in: JNES (6), 1947, pp. 169-179, pls. IV- VII; Walters, E., Attic Grave Reliefs that represent Women in the Dress of Isis, Hesperia Supplement XXII, Princeton, 1988, pp.20-25

135. Merkelbach, R., "Der Eid der Isismysten", in: ZPE (1), 1967; id., Isis Regina -Zeus Serapis. Die Griechisch Ägyptische Religion nach den Quellen Dargestellt. Stuttgart and Leipzig, 2001, pl.216. Normally the garments of priests and other members of the Isiac cult are long, and they did not wear headdress or false-beard, most probably they appeared with long garment, a natural hair and a beard like the male figure on the entrance of the burial chamber of Tomb 1897 of Von Bissing at Akhmim, was acted as priest of Isis. Venit, M., "Referencing Isis in Tombs of GrecoRoman Egypt", pp.106-107. Other examples of Isis priests outside Egypt, the paintings from Herculaneum: Arslan, E., Iside: Ilmitoilmistero la Magia, Milano, Palazzo Reale (22), 1977, p.447, no. V.77; a column base in the Vatican of the $3^{\text {rd }}$ century A.D. Lippold, Die Skulpturen des Vaticanischen Museums, Berlin, 1908, p.270, no.40. Also an plaque in the Vatican. Amelung, W., Die Skulpturen des Vaticanischen Museums II, Berlin, 1908, pp.143-145. Also found on a frontally- posed cleric on a coffin board, decorated in relief wears a thigh-length garment tied just below his pectorals. Bianchi, R., Cleopatra's Egypt: Age of the Ptolemies, Brooklyn Museum, 1988, p.240, no. 129; Venit, M.," Ancient Egyptomania: The Uses of Egypt in Graeco- Roman Alexandria", in: Leaving No Stones Unturned: Essays on the Ancient Near East and Egypt in Honor of Donald P. Hansen, (ed. By. Ehrenberg, E), Winona Lake, 2002, p. 274, no. 39

${ }^{136}$. Venit, M., Ancient Egyptomania, p. 274

137 . Venit, M., Monumental Tombes of ancient Alexandria, pp. 148-150

${ }^{138}$. Carton, G., Op. Cit, p. 97

139. Empereur, J., Alexandria redecouverte, Paris, 1998, p.17

140. Picard, Ch., "L'hypogee alexandrine de la rue Tigrane Pacha reconstitué a Kom el-chougafa", RevArch, janvier-Juin 1965 , p. 98

${ }^{141}$. Venit, M., " Referencing Isis in Tombs of Graeco- Roman Egypt", p. 109; id., "The Tomb from Tigrane Pasha Street and the Iconography of Death in Roman Alexandria", in: AJA (101), October 1997, p. 724; id., " Style, Substance, and the Efficacy of the Image in Tomb Painting of Roman Alexandria", in: Actes du VII Colloque international pour la Peinture murale antique, Saint-Romin-en-Gal, 6-10 October 1998, in: "La Painture funeraire antique, IV Siècle av. J.CIV Siècle ap. J.C, (ed. by. Barbet, A), Paris, 2001, p. 140; id., Monumental Tombs of Ancient Alexandria, 2002, pp. $148-149,158$ 
142. Tigrain's tomb uses Egypt in ways not found elsewhere in Alexandrian tomb design at all, the position of Egyptian deities with classical forms, it reuses and reinterprets the iconographic signs of Ancient Egypt, the rhetorical power of the Tigrain tomb emphasizes the term of "Egyptomania" by the Romans, both in Egypt and Rome. See: Venit, M., "Ancient Egyptomania, pp. 261-278. The human figure is similar to a bronze- statue of the Roman period, now in the Staatlichen Sammlung Ägyptischer Kunst de Munich (inv. AS 4202) represent Isis- Magic in a Greek -form with the knot of Isis, holding Situla in her left hand, while a serpent is coiled around, and looking forward on her right hand. Cartron, G., Op. Cit, p. 97

${ }^{143}$. Fraser, P., Ptolemaic Alexandria, Vol (II), p.206. Schauenburg, K., " Pluton and Dionysos", in: JdI (68), 1953 , pp. 71 72

${ }^{144}$. Osiris has a great cult in Canopus and Hierkleion on Abu Qir bay at Alexandria as Osiris-Canope. A temple was built by Ptolemy III to him and has special mysterious Dionysiaque rites and secrets inside it. See: Yoyotte, J., "Osiris dans la Region d' Alexandrie", in: Le Culte d' Osiris au I ${ }^{\mathrm{er}}$ Millenium AV.J.C. Découvertes et Travaux Récents, Actes de la table ronde Internation etenue a Lyon Maison de l'orient et de la Méditerranée (UniversiteLumiere- Lyon2) les 8 et 9 Juillet 2005. (ed. by Coulon, L), IFAO, Cairo, 2010, pp.33-38

${ }^{145}$. Nassery, S and Wagner, G., "Nouvelles Steles de KomabuBellou", in: BIFAO (78), 1978, , P. 258, pl. LXXXVI, no. 58

146. Tomb of Pakenrenef (Bocchoris), the vizier of Pesmatik I, north of the valley temple of Ounas - one of the shrouds found in the southern shaft of the tomb. Two Apis-bulls painted white on the right hand animal, and green with a purple band on the other- from which their heads and necks emerge, the heads topped with curly locks, two horns with the sun -disc in between and the two feathers surmounted the bull's head. They are shown left of the deceased who are depicted as Osiris, behind them stands a figure of Anubis as embalmer, the tomb was discovered by Bresciani, the University of Pise in Italy with the collaboration of the Saqqara Antiquities service. See: Bresciani, E., " A Propos de la Toile Funéraire Peinte Trouvée Récemment a Saqqara", in: BSFE (79), Juin 1976, pp. 5-24

147 . Kaplan, I., Op. Cit, p. 82

148 . Venit, M., Op. Cit, p. 247 , note. 845

149. The worship of the sacred bulls such Apis, Mnevis and Buchis was famous during the Greco-Roman period. The Apis cult at Memphis was connected also with the bull Mnevis, the bull of Heliopolis, they are portrayed together on the dedications of devotees from an earlier date, and the Ptolemaic connections have already been noted and well documented from all periods, Diodorus mentioned the new living revered Apis before his installation at Memphis must spent forty days in Nilopolis- the city on the east bank of the Nile close to Old Cairo. In the Ptolemaic period, Apis and Mnevis might share an embalmer -in- chef, and the same police officer (Chaiapis under Ptolemy II) carried responsibility for law and order during their festivals. Where there was a visit held by the bull Mnevis from Heliopolis to Memphis on 29 May 182 B.C. was the occasion for yet another priestly synod (the former was 29 October 185 B.C) in the city. See: Thompson, D., Op. Cit, pp. 46, pl. V, 120, 235.See: Daressy, G., "Un Decret de l'an XXIII de Ptolemee Epiphane", in: Rec Trav (33), 1911, pp.1-8, While the Buchis bull worshipped at Hermonthis, the modern Armant, to the north-west of the Montou precinct was the Bucheum, the necropolis of the scared Buchis bulls, bordered on the east by necropolis for the sacred cows who were the mothers of Buchis. See. Mond, R and Myers, O., The Bucheum, 3 Vols. London: Egypt Exploration Society, 1934; Goldbrunner, L., Buchis, Eine Untersuchnung zur Theologie des heiligen Stieres in Theban zur grieschich-römischenZeit, Turnhout, Belgium, 2004.The Bucheum still in use till 340 A.D; the fifty-seventh year of the era of Diocletian. Hölbl, G., Altägypten im Römerischen Reich: Der römische Pharao und sein Tempel, Vol (1), Mainz, 2000, p.45, nr. 178; Goldbrunner, L., Buchis: Eine Untersuchnung zur Theologie des heiligen Stieres in Theben zur griechisch-römischen Zeit, Turnhout: Brepols, 2004, pp.78-79; Minas- Nerpel, M., "Egyptian Temples", in: the Oxford Handbook of the Roman Period, Oxford, 2012, p. 362

${ }^{150}$. Abdel-Fattah, A., "The question of the Presence of Pharaonic Antiquities in the City of Alexandria and its Neighboring Sites (Alexandria pre-Alexander the Great), in: Egyptology at the dawn of the twenty-first century: proceedings of the Eighth International Congress of Egyptologists, (ed. by Hawass, Z and Lyla, P), Cairo, 2000 2, 63-72. Cairo; New York: American University in Cairo Press, p. 63

151. Whitehouse, H., Sacred Bovids: An unusual Terracotta Statuette from Roman Egypt", in: Sitting beside Lepsius, Studies in Honour of Jaromir Malek at the Griffith Institute, OLA (185), Leuven, 200, p.593

152 . Bresciani, E., Op. Cit, p.22

153. Though the top of the shroud represents only one bull on a shrine, facing right towards a cup of incense; it has a disk with uraeus between its horns, not two, but Bresciani. See: Bresciani, E., Il Volto di Osiris.Tele funeraire dipinte nell' Egittoromano, Lucca, 1996, p.39; Whitehouse, H., Op. Cit, p.593

${ }^{154}$. Otto, E., Beiträge zu Geschichte der Stierkulte in Ägypten, UGÄA (13), Hildesheim, 1964, pp.35-36

155. Whitehouse, H., Op. Cit, pp. 592-593; Bresciani, E., Op. Cit, pp.42-44

156. A hymn from the Ptolemaic period is inscribed on the propylon of Khonsou's temple at Karnak suggest this. See Derchain, P., Mythes et Dieux Lunaires en Egypte", La Lune, Mythes et Rites, Sources Orientales (5), Paris, 1962, pp. 19-68

157. Whitehouse, H., Op. Cit, p.594

158. Kucharek, A., Altägyptische Totenliturgien, Die Klagelieder von Isis und Nephtys in Texten der GriechischRömischen Zeit, Band (4), Heidelberg, 2010, p. 655 
159. Otto, E., Op. Cit, UGÄA (13), pp.13-14; Bonnet, H., " Apis", in: Lexikon der äg yptischen Religionsgeschichte, Hamburg, 2000, p.49; For more details see: Wiedemann, A., "Der Apis als Totenträger", in: OLZ (20), Leopzig, 1917; pp.298-303

160. Allen, T., The Book of the Dead or Going Forth by Day, Ideas of the Ancient Egyptians Concerning, the Hereafter as expressed in their own Terms, SAOC (37), Chicago, 1974, pp. 157-158

161. This scene is depicted from the third intermediate period, Late period and Ptolemaic period as the papyrus of Amun Iufankh at Bawiti, Bahariya Oasis. Munro recorded 29 example of the formula inscribed on the papyri. See Munro, I., Spruchvorkommen auf Totenbuch-Textzeugen der Dritten Zwischenzeit, in:SAT (5). Wiesbaden, 2001, pp-88-89; Quirk, Book of the Dead, p.394

162. Allen,T., Op. Cit, pp. 157-158

163. Quirk, S., Op. Cit, p. 395; Wüthrich, A., Eléments de Théologie Thébaine: les Chaptires supplémentaire du Livre des Morts, Wiesbaden, 2010, pp. 45, 52-53, 82-84.

164 . Kurth, D., Materialien zum Totenglauben im römerzeitlichen Ägypten, Hützel, 2010, p. 77, fig.5

165. Mosher, M., The papyrus of Hor (BM EA 10479), with Papyrus McGregor: Late Period tradition at Akhmim. Catalogue of the Books of the Dead in the British Museum, Vol. (II), London, The British Museum Press, 2001, pl. 3, frame 10

${ }^{166}$. Ibid, pl. 13 (2), frame 2

167. Lüscher, B., Das Totenbuch p.Berlin P. 10477 aus Achmim (mit Photographien des verwandten p.Hildesheim 5248), HÄT (6), Wiesbaden, 2000, fig. 6

168 . Mosher, M., Op. Cit, pl. 17 (1), frame 9

169. Kurth, D., Op. Cit, pp. 84-85. The crouching Apis bull, rest on a shrine appeared also on Papyrus Louvre No. 3279. Goyon, J., Le Papyrus du Louvre N. 3279, BdE (42), 1966.

${ }^{170}$. Clere, J., Le Papyrus de Nesmin, un Livre des Morts Hiéroglyphique de l'Epoque Ptolémaïque, Publications de l'IFAO, 1987, pl. IV

171. Dodson, A., "Four Sons of Horus", in: The Oxford Encyclopedia of Ancient Egypt, Vol. (1), Oxford University Press, 2001, pp.561-563;Seeber, C., Untersuchungen zur Darstellung des Totengerichtsim Alten Ägypten, MÄS (35),München,1976,Abb. 19; Marciniak, M., "Gercueil Anthropoide de Horus-Thot au Musée National de Varsovie", in: BIFAO (62), 1964, pl. XIII(b). Osing, J., Denkmäler der Oase Dachla, pl.22 (b); Kurth, D., Der Sarg der Teüris, p.56, pl. B

172. Möller, G., Die Papyri Rhind. In Anonymous (ed.), Das Totenbuch der Ägypter, Paderborn Voltmedia,2007, pl. VIII

173. Winlock, H., Bas-relief from the temple of Ramses I at Abydos, New York, 1921, pl.1; Davies, N., The temple of Hibis in el Khargeh Oasis. Part III, The Decoration, (ed.by Bull, L and Lindsley F. Hall), New York, 1953, pl.25

${ }^{174}$. Osing, J., Op. Cit,p. 78

${ }^{175}$. Quirk, S., Op. Cit, p. 313

${ }^{176}$. Venit, M., "Referencing Isis in Tombs of Graeco- Roman Egypt", p. 97

177. Osing, J., Op. Cit, pl.25 (a)

${ }^{178}$. Venit, M., Op. Cit, p.94; Gabra, Setal., Rapport sur les Fouilles d‘ Hermoupolis Ouest (Touna el-Gebel), Imprimerie de IFAO, Le Caire, 1941, pl. XII (1)

${ }^{179}$. Ibid, p. 94; Gabra, Setal., Op. Cit, pl. XV (2)

${ }^{180}$. Kessler, D and Brose, P., Ägyptens Letzte Pyramide, Das Grab des Seuta (s) in Touna el-Gebel, Patrick Brose, 2008

181. Flossmann, M and Schütze, A., "Ein Römerzeitliches Pyramidengrab und seine Ausstattung in Tuna el-Gebel, Ein Vorbericht zu den Grabungskampagen 2007 und 2008", in: Tradition and Transformation Egypt under Roman Rule, Proceeding of the International Conference, Hildesheim, Roemer, and Pelizaeus- Museum, 3-6 July 2008, (ed. By Lembke, K et al), Leuven, 2010, pp.91-93 ,pls.VI.5, 6,7; id.,Neue Ergebnisse der Grabung in Tuna el-Gebel: ein römerzeitliches Pyramidengrab und seine Ausstattung. Isched 2008 (2), Kessler, D and Patrick, B., Ägyptens letzte Pyramide: das Grab des Seuta(s) in Tuna el-Gebel, München: Verlag Patrick Brose, 2008

${ }^{182}$. Clere, J., Op. Cit, pl. 18

183. Mosher, M., Op. Cit, pl. 12

184. Lüscher, B., Op. Cit, fig. 20

185. Kapln, I., Op. Cit, fig.17, the tablet of Mensa- Isiaca, which is exhibited in the museum of Antiquities of Turin, show the close relation between the Apis bull and the Isiac cult in Rome. See Syndram, D., Die Ägyptenrezeption unter August dem Starken: der "Apis-Altar" Johann Melchior Dinglingers. Zaberns Bildbände zur Archäologie; Sonderbände der Antiken Welt. Mainz,1999, pp.30-31

${ }^{186}$. Alfano, C., "Egyptian Influence in Italy", in: Cleopatra of Egypt from History to Myth (ed. by Walker, S and Higgs, P), London, 2001, p. 284, fig.9.5 